\title{
Dış Borç ve Ekonomik Büyüme İlişkisi: Kamu ve Özel Sektör Dış Borçları Açısından BRICS-T Ülkeleri Analizi
} (Araştırma Makalesi)

The Relationship Between External Debt and Economic Growth: Analysis of BRICS-T Countries in Terms of Public and Private Sector External Debt Doi: 10.29023/alanyaakademik.867124

\section{Fazlı YILDIZ}

Doç. Dr., Kütahya Dumlupınar Üniversitesi, İktisadi ve İdari Bilimler Fakültesi Maliye Bölümü

fazli.yildiz@dpu.edu.tr

Orcid No:0000-0003-1387-7883

\section{Ersin Nail SAĞDIÇ}

Dr. Ögrr. Üyesi, Kütahya Dumlupınar Üniversitesi, İktisadi ve İdari Bilimler Fakültesi Maliye Bölümü

ersinnailsagdic@dpu.edu.tr

Orcid No: 0000-0002-4022-8515

Bu makaleye atıfta bulunmak için: Yıldız, F. \& Să̆dlç, E.N. (2021). "Dış Borç ve Ekonomik Büyüme İlişkisi: Kamu ve Özel Sektör Dış Borçları Açısından BRICS-T Ülkeleri Analizi”. Alanya Akademik Bakış, 5(2), Sayfa No.839-863.

\section{Anahtar kelimeler: \\ Dış Borç, Ekonomik \\ Büyüme, Kamu ve \\ Özel Sektör Dış \\ Borcu, Panel ARDL \\ Analizi \\ Makale Geliş Tarihi: \\ 23.01.2021 \\ Kabul Tarihi: \\ 17.02.2021}

External Debt, Economic Growth, Public and Private Sector External Debt, Panel ARDL Analysis

JEL Classification Codes: F34, F43, H63, C33

\section{ÖZET}

Bu çalışmada, 1997-2019 yılları arasında BRICS-T ülkelerinde dış borç bileşenlerinin (Kamu ve özel sektör diş borçlart) ekonomik büyüme üzerindeki etkisi incelenmiştir. Değişkenler arasındaki uzun ve kısa dönemli ilişski Havuzlanmış Ortalama Grup (PMG) Tahmincisi ile incelenmiştir. PMG tahmincisinden elde edilen sonuçlara göre tüm ülkeler bazında toplam diş borç, kamu dış borcu ve özel sektör diş borcunun ekonomik büyüme üzerinde uzun dönemde negatif etki gösterdiği tespit edilmistir. Ayrıca, ekonomik büyüme üzerinde en yüksek olumsuz etkiye sahip borç bileşeni kamu dış borçlarıdır. Araştırmanın ampirik sonuçları, borçluluk düzeyi yüksek olan ülkelerin ekonomik büyüme olanaklarının kısıtlanacağını savunan "Borç Fazlası Hipotezi" ile uyumludur.

\section{ABSTRACT}

In this study, the effect of external debt components (public and private sector external debt) on economic growth in BRICS-T for the 1997-2019 period is examined. Pooled Mean Group (PMG) Estimator method is used to determine the long term and short term relationship between the variables. According to the results based on PMG, it is determined that all debt components of BRICS$T$ countries have negative effect on economic growth in the long term. Moreover, public debt has the greatest negative impact on economic growth for these countries. These results are consistent with the "Debt Overhang Theory", which argues that economic growth opportunities of countries with high debt levels will be restricted. 


\section{GİRISŞ}

Dış borcun bir ülkenin ekonomik kalkınmasındaki rolü, araştırmacılar ve politikacılar arasında en çok tartışılan ve makroekonomi alanında ilgi çekici konulardan biridir. Özellikle gelişmekte olan ülkelerde dış borçlanma yatırım ve teknoloji transferini artırarak büyümeyi teşvik ettiğinde bu ülkelerin ekonomik kalkınma sürecine önemli bir katkısı olacaktır. Verimli bir şekilde kullanılmadığında ise artan dış borç yükü, ekonomik kalkınma ve büyümeyi olumsuz yönde etkileyecektir (Nath, 2020: 60). Dış borçların ekonomi üzerinde doğrusal olmayan etkileri olabilir. Bu nedenle, düşük borçlanma seviyelerinde, dış borcun GSYİH'ye oranındaki bir artış ekonomik büyümeyi teşvik edebilir; yüksek borçluluk seviyelerinde ise bu orandaki artış ekonomiye zarar verebilir (Casares, 2015: 220). Dış borcun GSYİH'ye oranının yüksek olduğu dönemlerde, reel döviz kurundaki düşüşle teşvik edilen ekonomik büyüme, diş borç servisi dolayısıyla yurt içi kaynakların yurt dışına transferine ve bunun sonucunda tasarrufların düşüşüne neden olmaktadır (Casares, 2015: 222).

Gelişmekte olan ülkeler, sermaye eksikliği veya yerel kaynakların kötü yönetimi nedeniyle tasarruflar ile yatırım, gelir ve harcama arasındaki uçurumu kapatmayı başaramamışlardır. Düşük ekonomik büyüme, yüksek işsizlik, yoksulluk ve gelir eşitsizliği gelişmekte olan ülkelerin en büyük sorunları arasında yer almaktadır (Zhang vd., 2020: 607). Ekonomik kalkınmasını hızlandırmak isteyen gelişmekte olan ekonomiler, yetersiz yurt içi tasarruflardan kaynaklanan sermaye eksikliklerini desteklemek için genellikle dış kaynaklara ihtiyaç duymaktadırlar. Çünkü hem özel hem de kamu sektörlerinde yatırımların finansmanında iç tasarrufların yetersizliği nedeniyle düşük büyüme oranları ile karşı karşıyadırlar. Bu çerçevede, bu ülkelerde yerel kaynaklardan sağlanan fonlar ile yatırım talebi arasında farklılık olduğu için finansman açığı sorunu ile karşılaşılır. Yatırım düzeyi ile tasarruf düzeyi arasında ulusal kaynaklardan karşılanamayan finansman açı̆̆ı yurt dişı kaynaklarla karşılanarak giderilebilmektedir (Abdullahi vd., 2016: 271-272).

Ekonomi literatüründe, aşırı dış borç yükünün yatırımı ve üretimi olumsuz etkilediği doğrudan ve dolaylı bazı kanallar aracılığıyla belirtilmektedir. Bu kanallar; yatırıma yönelik azalan teşvikleri ifade eden borç fazlası (yükü) etkisi, uluslararası krediye erişimin engellenmesi nedeniyle yükselen yurt içi reel faiz oranları, ekonomik faaliyetteki gerileme nedeniyle düşük kârlılık ve özel yatırımların tamamlayıcısı konumundaki kamu yatırımlarındaki azalmadır (Karagöl, 2002: 40). Borçlanmadaki artış, faiz oranlarında artışa neden olacak, bu durum da hem yatırım hem de tüketim için borçlanma maliyetini daha pahalı hale getirecek ve ekonomide dışlama etkisi oluşacaktır. Ayrıca, gelişmekte olan ülkelerdeki kötü yönetim, borçlanmanın bu ülkelerin hem ekonomik büyümesini hem de finansal sürdürülebilirliğini olumsuz etkilemesine neden olmaktadır. Dış borçlanma ile ilgili temel risk, dış borcun ulusal geri ödeme kabiliyetlerine göre sürdürülebilir bir seviyeyi aşmasıdır. Gelişmekte olan ülkelerde dış borçlanmanın ana maliyeti, gelecekteki gelirlerinden ödemek zorunda oldukları borç servisi maliyetleridir (Kharusi ve Ada, 2018: 1143).

Kamu ve özel kesimin yüksek düzeyde dış borçluluğu ekonomik büyümeyi ve gelecekte kaynak dağılımını etkilemektedir. Dış borçlanma ile ilgili literatür, ülke bazlı ağırlıklı olarak gelişmekte olan ekonomilere veya ülke gruplarına odaklanmış çalışmalardan oluşmaktadır. Farklı çalışmalarda gelişmekte olan ülkeler için sürdürülebilir kalkınma ve ekonomik büyüme hedefi doğrultusunda rasyonel politikalar oluşturmak için dış borç ile ekonomik büyüme ilişkisi incelenmiştir. Mevcut teorik ve ampirik literatür, dış borç ve ekonomik büyüme bağlantısına 
ilişkin dış borcun (kamu dış borcu, özel dış borç) ekonomik büyümeyi ne yönde etkilediğini ve bu iki değişken arasındaki nedensellik ilişkisini araştırmaktadır. Bu çalışmanın literatürdeki çalışmalardan farklı olarak getirdiği yeniliklerden birincisi, dış finansmana erişimde var olan koşullardaki farklılık sebebiyle dış borcun kamu ve özel sektör dış borcu olarak ayrıştırılarak analize dâhil edilmesidir. İkincisi, gelişmekte olan ülkeler dış borç stokunun \%54'üne sahip olan BRICS-T ülkelerinin (Brezilya, Rusya, Hindistan, Çin, Güney Afrika ve Türkiye) örneklem olarak tercih edilmesi, kamu ve özel kesim dış borcunun ekonomik büyüme üzerindeki kısa ve uzun dönemli etkisinin panel ARDL yöntemi kullanılarak incelenmesidir.

Çalışma giriş bölümünü takip eden beş bölümden oluşmaktadır. İkinci bölümde dış borçlanmaya ilişkin kavramsal çerçeve ve BRICS-T ülkelerinin diş borçluluk göstergeleri üzerinden dış borç yapıları incelenmiştir. Üçüncü bölüm, dış borç ve ekonomik büyüme ilişkisinin teorik çerçevesinin farklı teorik yaklaşımlar temelinde incelendiği bölümdür. Dördüncü bölüm, dış borç ve ekonomik büyüme ilişkisine dair Türkiye ve yabancı ülkelere yönelik ampirik çalışmaların özetlendiği bölümdür. Beşinci bölümde, tahmin modeli, ampirik analizler ve sonuçları tartışılmış, devamında altıncı bölümde sonuç kısmı ile çalışma tamamlanmıştır.

\section{KAVRAMSAL ÇERÇEVE VE BRICS-T ÜLKELERINDE DIŞ BORÇ YAPISI}

Dış borç ${ }^{1}$, belirli bir dönemde bir ülkenin yerleşikleri (genel hükümet, işletmeler, bireyler ve özel sivil toplum kuruluşları) tarafından yerleşik olmayanlara (yurt dışı) karşı gelecek dönemlerde anapara ve/veya faiz ödeme yükümlülüğü gerektiren şarta bağlı olmayan fiili ve cari yükümlülüklerdir (IMF, 2003: 7). IMF ve diğer uluslararası kuruluşların dış borca ilişkin tanımda önemsediği ilke yerleşikliktir. Bu ilkeden hareketle, uluslararası dış borç istatistikleri sınıflandırmasında dış borçlanma işlemlerinde borç verilen para birimi ve borç verenlerin (kreditörler) uyrukluğu gibi ölçütler tercih edilmemektedir. Dış borca ilişkin yerleşiklik ilkesi temelinde esas alınan bu tanımlama, borç stokundaki değişikliklerin ve uluslararası risk paylaşımının GSYİH üzerindeki etkilerinin ölçülmesi ve dış borçlanmada moratoryum gibi politik maliyetlerin değerlendirilmesine imkan sağlamaktadır (Pata ve Ela, 2020: 6-7). BRICST (Brezilya, Rusya, Hindistan, Çin, Güney Afrika ve Türkiye) ülkeleri ile ilgili 2009-2019 dönemine ilişkin dış borç yapısı göstergeleri aşağıda Tablo 1'de sunulmuştur.

Tablo 1. BRICS-T Ülkelerinde Dış Borç Yapısı Göstergeleri (2009\&2019)

\begin{tabular}{|c|c|c|c|c|c|}
\hline Ülkeler & llar & $\begin{array}{c}\text { Diş } \\
\text { Borç } \\
\text { Stoku / } \\
\text { GSMH } \\
(\%)\end{array}$ & $\begin{array}{c}\text { Kısa Vadeli Dış } \\
\text { Borç Stoku / } \\
\text { Toplam Dış Borç } \\
\text { Stoku } \\
(\%)\end{array}$ & $\begin{array}{c}\text { Kamu Dış Borç } \\
\text { Stoku / Uzun } \\
\text { Vadeli Dış Borç } \\
\text { Stoku } \\
(\%)\end{array}$ & $\begin{array}{l}\text { Özel Sektör Dış } \\
\text { Borç Stoku / Uzun } \\
\text { Vadeli Dış Borç } \\
\text { Stoku } \\
(\%)\end{array}$ \\
\hline Brezilya & 2009 & 17 & 14 & 37 & 63 \\
\hline
\end{tabular}

\footnotetext{
${ }^{1}$ Dünya Bankası tarafından yapılmış ve genel olarak ülkelerin tercih ettiği sınıflandırmaya göre dış borçlar; "Toplam dış borçlar, ülkede yerleşik olmayan kreditörler tarafindan sağlanan kısa ve uzun vadeli borçlar ile IMF kredilerinin toplamını kapsamaktadır. Dış borçlar borçlular açısından sınıflandırıldığında garantisiz özel sektör dış borçları, kamu kesimi dış borçları ve kamu garantili dış borçlar olarak sınıflandırllmaktadır. Ayrıca, dış borçlar kreditörler yani borç verenler açısından sınıflandırıldığında ise, resmi kreditörler (çok taraflı [uluslararası kuruluşlar] ve iki taraflı [devletler]) ve özel kreditörler (ticari bankalar, uluslararası piyasalarda ihraç edilen tahviller ve diğerleri)" olarak siniflandirılır (World Bank, 2020: 167).
} 


\begin{tabular}{lccccc}
\multirow{5}{*}{ Çin } & 2019 & 32 & 14 & 40 & 60 \\
\multirow{3}{*}{ Güney Afrika } & 2009 & 9 & 53 & 50 & 50 \\
\multirow{3}{*}{ Hindistan } & 2019 & 15 & 57 & 35 & 65 \\
\multirow{2}{*}{ Rusya } & 2019 & 28 & 27 & 42 & 58 \\
\multirow{2}{*}{ Türkiye } & 2009 & 19 & 18 & 57 & 43 \\
& 2019 & 20 & 18 & 42 & 58 \\
& 2019 & 34 & 19 & 43 & 57 \\
\hline
\end{tabular}

Kaynak: World Bank (2020), International Debt Statistics 2021, s. 47-141.

BRICS-T ülkelerinin dış borç stoku (4,393 milyar US\$), toplam gelişmekte olan ülkeler diş borç stokunun (8,139 milyar US\$) \%54'üne denk gelmektedir. BRICS-T ülkeleri arasında Çin, Brezilya, Rusya, Hindistan ve Türkiye'nin dış borçluluk düzeyi Güney Afrika'ya göre daha yüksektir (World Bank, 2020: 6). BRICS-T ülkelerinde; 2019 yılında dış borç stoku GSMH oranı çok borçluluk kriteri ${ }^{2}$ olarak kabul edilen \%50'nin üzerinde olan ülkeler; Türkiye (\%59) ve Güney Afrika (\%55)'dır. 2019 yılında kısa vadeli dış borçların toplam dış borç stoku içindeki payı en yüksek olan ülke \%57 oranı ile Çin, en düşük paya sahip olan ülke ise \%12 ile Rusya'dır. BRICS-T ülkelerinde 2019 yılında uzun vadeli dış borç stoku içinde kamu kesimi ve özel sektör dış borç stoku dağılımı incelendiğinde, Güney Afrika dışındaki ülkelerde özel sektör dış borçluluk oranı kamu sektörü dış borçluluk oranından yüksektir. Güney Afrika'da bu dağılım kamu sektörü \%57, özel sektör \%43, diğer BRICS-T ülkelerinde ise genel olarak kamu sektörü \%40, özel sektör ise \%60 düzeylerindedir. Özellikle Çin, Türkiye ve Brezilya'da özel sektör dış borçluluk oranı kamu sektörü dış borçluluk oranına göre daha yüksektir.

\section{DIŞ BORÇ VE EKONOMIK BÜYÜME ILIŞ̧ISISI: TEORİK LITERATÜR}

Literatürde dış borçlanma ve ekonomik büyüme ilişkisine dair 1950'li y1llardan günümüze tartışılan teoriler genel olarak, borçla büyüme modeli, ikili açık teorisi, borç fazlası teorisi ve dişlama teorisi olarak isimlendirilmektedir (Pata ve Ela, 2020: 45-46; Adedoyin vd., 2016: 180182; Abdullahi vd., 2016: 271-273; Bilginoğlu ve Aysu, 2008: 4-12). Tüm teorik modellerde dış borç, tasarruf ve döviz açıklarını kapatmak için kullanılmakta ve verimliliği artıran yatırımlara aktarılması önerilmektedir. Dış borç verimli alanlarda kullanıldığında ekonomik büyümeyi olumlu etkileyebilir. Ancak, verimsiz alanlarda kullanılan diş borçlar, sonraki dönemler için ülkelerin ödeme gücünü azaltacak ve borç fazlası (yükü) oluşturarak ekonomik büyümeyi olumsuz etkileyecektir (Toktaş vd., 2019: 2810).

\subsection{Borçla Büyüme Modeli (Growth - Cum - Debt Model)}

Gelişmekte olan ülkelerin tasarruf yetersizliği dolayısıyla gerçekleştirmekte zorlandığı yatırımları telafi etmek amacıyla dış borçlanmayı bir araç olarak kullanmaları gerektiğini kabul eden yaklaşımlardan biri borçla büyüme modelidir (Gürdal ve Yavuz, 2015: 157). Borçla büyüme modeli, ekonomik büyüme sürecinde dış borç servisi kapasitesini borçlanmanın

\footnotetext{
${ }^{2}$ Dünya Bankası ve Uluslararası Para Fonu'nun dış borçluluk açısından ülkelerle ilgili kullandığı çok borçluluk göstergeleri; Toplam Dış Borç/GSMH > \% 50, Toplam Dış Borç/İhracat > \% 275, Dlş Borç Servisi/Ihracat > \% 30 ve Dlş Borç Faiz Servisi/İhracat > \% 20 (Erkan vd., 2012: 315-316). 
faydaları ve maliyetleri açısından ele almaktadır. Teori, ülke içi yatırım ve tasarruf arasındaki boşluğu doldurmak için yatırım amaçlı gerçekleştirilen dış borçlanma anlayışına dayanmaktadır. Model, zaman içinde ülkenin borcuna yapılan ilavelerin ekonomik büyümeye katkıda bulunması koşuluyla bir ülkenin borç ödeme kapasitesini koruyacağını varsaymaktadır. Borçla büyüme modelinin esası, borçlanma stratejisinin ekonomik büyümeye katkı sağladığ1 sürece işe yarayacağını ve desteklenmesi gerektiğini ifade etmektedir (Oluseyi, 2013: 3). Modele göre, sürdürülebilir diş borç servisi kapasitesi, borçlanma faiz oranları sonucunda belirlenen borçlanma maliyetlerine eşit veya bu maliyetlerin üzerinde bir ekonomik büyüme sağlandığı koşullarda gerçekleşecektir (Kutlu ve Yurttagüler, 2016: 234). Ayrıca, yatırım amaçlı ürünlerin (sermaye malları) ithalatı sonucunda oluşan cari açık finansmanına yönelik kullanılan dış borçlanmanın ülkede yatırım seviyesinde artışa ve ekonomik büyümeye katkı sunması beklenmektedir (Bilginoğlu ve Aysu, 2008: 7).

Ancak borçla büyüme modeli, yalnızca tasarruf-yatırım boşluğuna odaklanması, dış finansmanın yabancı para cinsinden sağlanarak döviz olarak geri ödenmesi ve dolayısıyla tasarruf fazlasının dövize çevrilerek yurt dışına transfer edilme zorunluluğu ve borçlu ekonominin dışa yönelik çalışan sektörlerinin performanslarını dikkate almaması yönüyle eleştirilmektedir (Oluseyi, 2013: 4). Borçla büyüme modeli varsayımları içerisinde kullanılan dış kaynakların olumlu etkileri bazı faktörlere bağlıdır. Bu faktörler, yurt dışı kaynakların yatırıma dönüşme sonrası gelir yaratma sürecindeki verimlilikleri, yurt dışı kaynakların kullanımı sonucu elde edilen gelirlerin tasarrufa dönüşme ve yurt içi yatırıma dönüşüm oranı, yurt dışı kaynakların maliyet (faiz) ve edinilme koşulları (vade ve geri ödeme koşulları vb.)' dır (Bilginoğlu ve Aysu, 2008: 6).

Dış borcun ekonomik büyümeye aktarım kanallarını nasıl etkileyebileceğine ilişkin yedi temel alan vardır. Bu alanlar, özel tasarruflar, kamu yatırımları, çalışan kişi başına reel GSYİH, özel sektörde çalışan kişi başına brüt katma değer, özel sektör toplam faktör verimliliği, özel sektör yatırımları ve birincil gelir hesabıdır (Silva, 2020: 611-612). Dış borç stoku ve faiz oranlarının seviyesi, gelecekteki faiz ödemelerinin miktarını belirleyerek bireylerin gelirinde azalışa ve dolayısıyla daha az tüketim ve tasarrufa neden olmaktadır. Özel sektör dış borcu faiz oranından daha yüksek bir yatırım getirisi elde edebilirse, özel sektör dış borcunun verimlilik ve ekonomik büyüme üzerinde olumlu bir etkisi olabilir (Silva, 2020: 612). Kamu diş borcu, kamu yatırımlarının finansmanına katkı sağladığı gibi, kamu sektörünün yüksek dış borç stoku, yabancı kuruluşlara yüksek düzeyde ödeme yapılmasını ve birincil gelir hesabında azalmaya neden olmaktadır. Ayrıca, yüksek miktardaki faiz ödemeleri, devlet bütçesinde kamu yatırımları ile ilgili projeleri finanse etmek için ihtiyaç duyulan mali alanın daralmasına yol açar. Hükümet, mali konsolidasyon amacını göz önünde bulundurarak, kamu altyapısının oluşturulması ve sürdürülmesi de dahil olmak üzere, kamu yatırımları için tahsis edilen birincil harcamaları azaltabilmektedir. Yüksek borç faiz ödemeleri, kamu bütçesinde kullanılabilir kaynakları azaltarak sosyal transferlere ve kamu yatırımlarına ayrılacak kaynakları olumsuz etkiler (Silva, 2020: 611). Diş borçlanma belli bir eşik seviyesine ${ }^{3}$ ulaştıktan sonra ek borcun ekonomik büyüme üzerindeki olumlu etkileri giderek azalacaktır. Az gelişmiş ekonomilerde sermayenin sınırlı olmasından dolayı bu ülkeler sermaye getirisi fon maliyetlerinin üzerinde

${ }^{3}$ Eşik değer, ekonomik büyüme seviyesinde azalışa neden olan dış borçluluk düzeyindeki dış borç / GSYİH oranı için kullanılmaktadır. 
olduğu seviyeye kadar diş borçlanma yapma konusunda desteklenmektedirler (Pattillo vd. 2004: 5).

\section{2. İkili Açık Teorisi (The Dual Gap Theory)}

İkili açık modeli, dış borçlanma ile ekonomik büyüme arasındaki ilişkiye farklı bir bakış açısı getirmiştir. Bu modelin ana argümanı, birçok gelişmekte olan ülkenin sermaye veya ara malı ithalatını finanse ederken döviz açığı ve yerli yatırımların finansmanı için yurtiçi tasarruf eksikliği ile karşı karşıya olduğudur. Tasarruf açığı ve döviz açığı, gelişmekte olan ülkeler için istenen büyüme düzeyine ulaşma kabiliyetini sınırlamaktadır (Toktaş vd., 2019: 2808). İkili açık teorisi, ekonomik büyümeyi yatırımın bir fonksiyonu olarak kabul ederek yatırımın yurtiçi tasarrufların bir ürünü olduğunu ve yatırım için yurt içi tasarrufların yetersiz olduğunu varsaymaktadır. $\mathrm{Bu}$ senaryo dikkate alındığında, hükümetler ekonomide yatırıma yönlendirilecek kaynağın yurt dışından temin edilmesi stratejisini benimsemektedirler. Ayrıca, yurtiçi kaynakların yetersizliğinde ithalatın ihracatı aşan kısmı kadar bir kaynak yurt dışından borçlanma yoluyla ülkeye getirilmektedir. Bir ülkede tasarruf eksikliği sonucu tasarruf ile yatırım arasındaki fark tasarruf açığını, ithalat fazlalığından dolayı ithalat ile ihracat arasındaki fark ise döviz açığı sorununa neden olur. Bir ekonomide ikili açık koşullarının oluştuğu bu durum şöyle formüle edilmektedir (Adedoyin vd., 2016: 181):

$$
\text { Yatırım (I) - Tasarruf (S) = İthalat (M) - İhracat (X) }
$$

Bu denklik ikili açık teorisi analizinin temelidir. Bu teoriye göre, yurt içi tasarruf düzeyi hedef büyüme oranının gerçekleştirilmesi için gereken seviyenin altına düşerse, tasarruf-yatırım açığının var olabileceği ve dolayısıyla borçlanmanın tetiklendiği açıklanmaktadır. Benzer bir şekilde, büyüme hedefini gerçekleştirmek için gereken maksimum ithalat gereksiniminin, mümkün olan maksimum ihracat seviyesinden daha büyük olduğu durumda borçlanmaya ihtiyaç duyulacaktır (Adedoyin vd., 2016: 181). Esasen ikili açık kavramı, ekonomik kalkınma sürecindeki yabancı kaynak kullanımının işlevini ortaya koymaktadır. Böylelikle tasarruf ve döviz açığı vasıtasıyla gelişmekte olan ülkelerin yurtiçi sermaye birikimlerinden daha fazla yatırım yapmalarına olanak tanınır (Abdullahi vd., 2016: 272).

\subsection{Borç Fazlası Teorisi (Debt Overhang Theory)}

Dış borç ve ekonomik büyüme ilişkisine dair teorilerden en yaygın olanı "Borç Fazlası Teorisi" dir. Bu teori ilk kez Myers (1977) tarafından şirketlerin borçlanma kararlarına yönelik tartışılmıştır. Myers (1977), borçlu şirketlerin gelecekteki nakit akışlarının bir kısmının, taahhüt edilen ödemeler şeklinde alacaklılara aktarılarak şirketin yatırım politikası için caydırıcı etkiler yaratacağı görüşünü savunmuştur. Daha sonra Krugman (1988) ve Sachs (1989), Myers (1977) yaklaşımını bir ülkenin dış borçluluk durumuna, borç ödeme yükümlülüklerini yerine getirme kabiliyetine ve ödeme alan alacaklıya nasıl fayda sağlayacağına uyarlayarak ülkeler düzeyinde incelemişlerdir. Borç fazlası, bir ülkedeki dış borç stokunun, bir ülkenin geri ödeme kabiliyetini gelecekte aşması durumunda ortaya çıkan bir durumdur. Krugman (1988) ve Sachs (1989), ülkenin borç servisi yükünün, mevcut çıktının büyük bir kısmının yabancı borç verenlere aktarılacak kadar ağır olduğu ve sonuç olarak yatırımı caydırıcı hale getirdiği zaman, borç fazlalığının var olduğunu belirtmişlerdir. Yüksek seviyelerdeki dış borçlanmanın daha düşük ekonomik büyümeye sebep olacağına ilişkin teorik yaklaşım, Krugman (1988) tarafindan "Borç Fazlası (Debt Overhang)" ve Sachs (1989) tarafından "Borç Laffer Eğrisi”” yaklaşımları ile açıklanmaktadır (Doruk, 2018: 97). 
Krugman (1988), borçlu ülkelerin gelecekteki potansiyel kaynak transferlerinin beklenen bugünkü değerinin, borç miktarından daha az olduğu durumda borç fazlası sorunu ile karşılaştıklarını belirtmiştir. Sachs (1989) tarafından geliştirilen beklenen borç geri ödemeleri ile dış borç düzeyi ilişkisini inceleyen Borç Laffer eğrisi ilk versiyonunda, daha büyük borç stoklarının daha düşük borç geri ödeme olasılıkları ile ilişkili olma eğiliminde olduğu belirtilmektedir. Ters-U şeklindeki Borç Laffer Eğrisi'nin (Şekil.1[a]) yukarı eğimli veya "iyi”" bölümünde, borcun nominal değerindeki artışlar beklenen borç geri ödemesindeki artışlarla ilişkilendirilirken; borç miktarındaki artışlar borcun aşağı doğru eğimli veya “kötü” bölümünde beklenen borç geri ödemesini azaltmaktadır. Husain (1997), borç fazlası etkisinin hem alacaklının borçlu hükümetten geri ödeme alma kabiliyetine, hem de borçlu hükümetin vatandaşlarından gelir elde etme kabiliyetine bağlı olduğunu ve alacaklının borçludan geri ödeme alma kabiliyeti ne kadar fazlaysa, yatırımlar üzerindeki ilave vergi yükünün o kadar yüksek oluşacağı ve borç fazlası etkisinin de o derece büyük olacağını belirtmiştir. Ülkelerin borçluluk düzeyleri eşik değerin üzerinde artış gösterdiği seviyeden itibaren borç çıkmazı (fazlası) etkisinin oluştuğu dönemlerde dış borçlanmanın ekonomik büyüme üzerindeki etkisi negatif yönlü olacaktır.

D1ş borç ve ekonomik büyüme ilişkisinin incelendiği Borç Laffer Eğrisi'nin ikinci versiyonu Elbadawi vd. (1997) tarafindan geliştirilmiştir. Borç Laffer Eğrisi'nin bu versiyonunda diş borç belirli bir seviyeye kadar ekonomik büyüme üzerinde artı̧̧ etkisi, belirli seviyeden sonra yatırım ve çıktı azalışından dolayı azaltıcı etki meydana getirmektedir. Borç Laffer Eğrisi (Şekil.1[b]) ilk yaklaşımında olduğu gibi ters-U şeklindeki yukarı eğimli veya "iyi”" bölümünde, düşük borçluluk düzeyinde yüksek büyüme oranı; aşağı doğru eğimli veya "kötü" bölümünde ise yüksek borçluluk düzeyinde düşük büyüme oranı gerçekleşmektedir. Dönüm noktası (A noktası), dış borç stokunun ekonomik büyüme üzerinde olumsuz etkileri olmaya başladığı sınırı göstermektedir. Bu yaklaşımda, dış borcun ekonomik büyüme üzerindeki etkisi cari borç akımı ve geçmişten itibaren süregelen borç yükü dikkate alınarak yatırımlar kanalıyla açıklanmıştır. Borç Laffer Eğrisi'nin bu yaklaşımına göre, borç akımının ekonomik büyüme üzerinde arttırıcı etkisi varken, borç yükünün borç fazlası hipotezi etkisiyle yatırımlar ve çıtı (ekonomik büyüme) üzerinde azaltıcı etkisi oluşmaktadır (Pata ve Ela, 2020: 60).

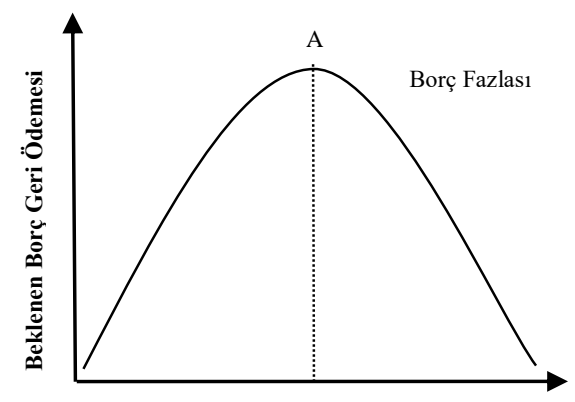

(a)

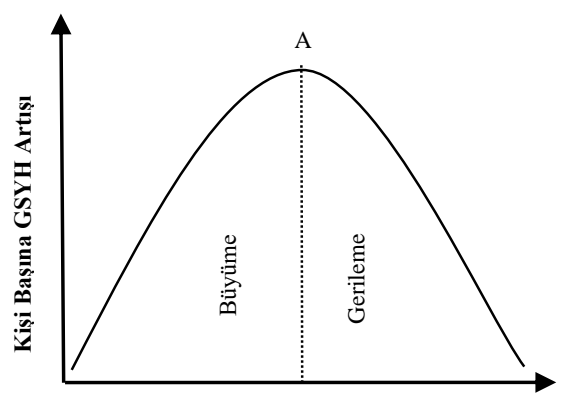

(b)

Dıș Borç Stoku/GSYİH

Şekil 1. Borç Laffer Eğrisi 
Kaynak: (a) Dao ve Oanh (2017: 4); (b) Elbadawi vd. (1997: 61).

Borç Laffer Eğrisinin ikinci versiyonunun sınanmasına yönelik ülkeler üzerine yapılmış olan çalışmalardan Dao ve Oanh (2017: 11) Vietnam'da dış borç ile ekonomik büyüme arasında doğrusal olmayan (ters $U$ şeklinde) ilişkinin varlığını \%28 eşik seviyesi olarak tespit etmiş, borç oranı zirve noktasının solunda kaldığında, dış borçtaki \%1'lik artış, ekonomik büyümenin $\% 0.52$ artmasına; tersine, borç oranı zirvenin sağındayken, zirveyi aşan her \%1'lik artış, ekonomik büyümede \%2.67 azalışa neden olacağı sonucuna ulaşmışlardır. Ayrıca, Tuffour (2012a: 74), Gana için 1970-2009 dönemini kapsayan araştırmada dış borç stoku/GSMH eşik değerini \%46, Felix (2020: 63) 15 ECOWAS ülkesi için kısa vadede \%45, uzun vadede ise \%42.5, Ndoricimpa (2020: 202) 39 Afrika ülkesi için \%62-\%66 aralı̆̆1, Ndoricimpa (2017: 477-478) \%92-\%102 aralığ1, Kazakova ve Inaba (2018: 450) \%61.3 olarak bulmuştur.

Literatürde, diş borçların ekonomik büyüme üzerindeki etkisinin analizinde temel dış borç rasyosunun (Dış Borç Stoku / GSMH) kritik eşiğin üzerinde seyredip seyretmediği durumlara göre ülke ekonomilerinde farklı etkilerin ortaya çıkması ihtimalinden söz edilmektedir. $\mathrm{Bu}$ kapsamda, dış borç rasyosu eşik değerden daha düşükse olumlu (pozitif) etki, eşik değerden daha yüksek ise olumsuz (negatif) etki beklentisinden söz edilmektedir. Beklenen pozitif etkiler; ek sermaye oluşumu, yatırım ortamı çekiciliğinde (cazibesi) artış, ekonomik yeniden yapılanma ile teknoloji ve yönetim becerilerinin transferinde artıştır. Negatif etkiler ise; borç yükünde artış, alacaklı ülkelere bağımlılığın artması, politika değişimi, ekonominin yeniden yapılandırılması ile ülke içi kaynaklardan yararlanma motivasyonunda düşüş ve kaynakların aşırı kullanımıdır. Beklenen pozitif etkilerin ekonomik büyüme üzerindeki etkisi artış yönlü, negatif etkilerin ekonomik büyümeyi etkileme yönü ise azalış şeklindedir (Dao ve Oanh, 2017: $5)$.

Borç fazlası hipotezi, dış borcun yatırımları olumsuz yönde etkilediğini vurgulamaktadır. Ayrıca, borç servisindeki artış borçlu ülkelerde gelirin çoğunun ekonomik büyüme yollarına geri dönme potansiyellerini azaltacaktır. Olumsuz ekonomik şoklar ve zayıf ekonomi politikaları alacaklıların kredi portföylerini ağır risklerle karşı karşıya bırakacağından potansiyel yeni kredi kaynaklarında azalışa neden olacaktır (Abdullahi vd., 2016: 273). Borç fazlası teorisi, gelecekte dış borcun ülkenin geri ödeme kapasitesinden daha büyük olma olasılığı varsa, beklenen borç servisi maliyetlerinin daha fazla yerli ve yabancı yatırımı caydıracağını ve ekonomik büyümeye zarar vereceğini öne sürmektedir. Yüksek borç servisi yükü, gelecekte özel sektör üzerinde beklenen vergileri artırarak, özel yatırımları azaltacaktır. Böylelikle yatırımlara yönelecek kaynaklar borç servisi ile tüketilecek ve ilave borç yükü, yatırım kalitesini düşürerek ekonomik performansı kötüleştirecektir (Sichula, 2012: 82). Borç fazlası hipotezi, birikmiş borcun gelecekteki üretim için bir vergi görevi gördügünü, özel sektörün üretken yatırım planlarını caydırdığını ve hükümetlerin temel fonksiyonlarını etkin yürütme çabalarını zayıflattığı görüşünü benimsemektedir (Karagöl, 2004: 69). Bir ülkenin borç düzeyinin ülkenin geri ödeme kapasitesini aşması bekleniyorsa, hükümet bu tür ödemelere hizmet etmek için gelirlerini artıracak, böylece ulusal gelirin büyüme oranı düşecektir. Bu durumda bir ülkenin ekonomisine yatırım yapmaktan elde edilen kârların bir kısmı, yabancı alacaklılara ödeme yapmak için vergilendirilecek, bu nedenle ekonomik büyüme kısıtlanacaktır (Dao ve Oanh, 2017: 4). Ülkelerde ağır bir borç yükünün varlığı, daha fazla borç geri ödeme yapılmasına ve kamu yatırımları dahil olmak üzere mali harcamaların kısılmasına neden 
olmaktadır. Bu durumda, borç azaltmanın özel yatırım üzerindeki etkisi sınırlı olsa bile uzun vadede kamu yatırımları üzerindeki etkisi olumlu olacaktır (Husain, 1997: 524).

\subsection{Dışlama (Crowding Out) Teorisi}

Klasik ve Monetarist görüşe göre, kamu borçlanmasındaki ve kamu harcamalarındaki artış para arzının genişlemediği koşullarda sınırlı miktarda fon elde etmek için özel sektör ve kamu kesimini tahvil piyasalarında rekabet eder hale getirerek, borçlanma piyasalarında faiz oranlarının artmasına neden olacak ve özel sektör yatırımlarını dışlayarak olumsuz etkileyecektir (Khan ve Gill, 2009: 5). Dışlama teorisine göre, yüksek borçluluk oranlarının diş borçlanma olanaklarını azaltması sonucunda ülkelerin ağırlıklı olarak iç borçlanmaya yönelmesi, ülke içinde kredi kısıtından dolayı faiz oranlarının yükselmesine neden olacak, bu koşullar ise özel kesim yatırımları üzerinde dışlayıcı etki oluşturacaktır. Yüksek dış borç servisi (dış borç ana para ve faiz ödemeleri), devlet tarafindan iç borçlanmanın marjinal olarak artmasına neden olmakta, bu durum yurtiçi faiz oranını yükselterek ödünç verilebilir fonlara olan talep artışıyla özel sektör iç borçlanma imkanlarını kısıtlamaktadır. Artan faiz oranı borçlanma maliyetini artırmakta ve dolayısıyla özel yatırımlarını azaltmaktadır. Genel olarak dış borç servisinin yüksek olduğu dönemlerde ülkedeki yatırım oluşumunu azaltan bu etki dişlama (crowding out) etkisi olarak ifade edilir (Tuffour, 2012b: 80-81). Dişlama teorisi yaklaşımına göre, dış borç servisinin yükselmesi yerel borçlanma piyasalarını olumsuz etkileyerek dış borç servisi aracılığıyla dışlama etkisi gerçekleşmektedir. Bu etki, kamu dış borç servisinin kamu yatırımları üzerinde olumsuz etkisiyle birleşerek özel kesim açısından tamamlayıcı nitelikteki kamu yatırımlarında azalışa neden olmakta ve ekonomik büyümeyi olumsuz etkilemektedir (Ela ve Pata, 2020: 35).

Ayrıca, özel sektörün dış borç miktarı özel yatırımlar üzerinde hem olumlu hem de olumsuz bir etkiye sahiptir. Bir yandan, dış borç miktarı, daha yüksek yatırımların finanse edilmesine ve sermaye stokunun artmasının yanı sıra ölçek ekonomileri ve bilgi gelişimine izin vermektedir. Öte yandan, yüksek düzeyde dış borç ve yüksek miktarda faiz, finansal olmayan şirketlerin yatırım yapma ve sermaye stokunu artırma kabiliyetini azaltmaktadır. Buna ek olarak, finansal kuruluşlar, yüksek kaldıraç kullanımı nedeniyle özel sektöre yönelik kredileri azaltmakta ve bu da finansal olmayan şirketlerin yatırımlarını olumsuz etkilemektedir (Silva, 2020: 612). Dış borç servisi ülke içi kaynakların yurt dışına aktarılmasına sebep olarak ekonominin kalkınma kapasitesini azaltırken aynı zamanda dış borçlara bağımlılığı artıran etkiler meydana getirmektedir (Abdullahi vd., 2016: 273). Yurt içi yerleşiklerden sağlanan kamu borcu (iç borç) ekonomik büyüme oranı için çok zararlı olmasa da yurt dişı yerleşiklerin elinde bulunan kamu borcu (dış borç) dış ödemeler bilançosu ve ekonomik büyüme üzerinde olumsuz sonuçlar doğurabilir. Ayrıca, özel sektörün dış borcu, özel sektör tarafından üretilen değerin bir kısmının ülke dışına dış borç faiz ödemesi olarak zorunlu olarak tahsis edilmesini gerektirmektedir. Net diş borcun sürdürülebilirliği, yerleşik kurumsal sektörlerin gelecekte kaynak üretme ve orta/uzun vadede yurt dışına faiz ödeme kapasitesine sahip olmasını ve dış borcun yenilenmesini tehlikeye atmadan potansiyel çıktı artışının azaltılmamasını gerektirmektedir (Silva, 2020: 608-609).

\section{LITERATÜR ÖZETI}

$\mathrm{Bu}$ bölümde, seçilmiş literatürün kısa bir incelemesi sunulmaktadır. Dış borç ile ekonomik büyüme arasındaki ilişkiye dair hem teorik hem de ampirik çalışmalar vardır. Ekonomik büyüme ve dış borç arasındaki ilişkinin literatürde dış borç/GSYİH oranına bağlı olarak 
incelendiği, dış borcun ekonomik büyüme üzerinde farklı etkilere sebep olduğuna ilişkin sonuçlara ulaşıldığı görülmüştür. Literatürde dış borç ve ekonomik büyüme arasındaki ilişki farklı dönemler ve farklı ülkeler için geniş çapta incelenmiştir. Türkiye ve yabancı ülkelerle ilgili olarak incelenmiş olan ampirik çalışmaların sonuçları, ülke/ülkeler, dönem ve kullanılan yönteme göre farklılıklar göstermektedir. D1ş borç ekonomik büyüme ilişkisinin araştırıldığg 1 ampirik çalışmalarda genel olarak borç fazlası hipotezi ve dışlama etkisi hipotezi sınanmıştır. Ampirik araştırmaların çoğunda, dış borç ve ekonomik büyüme arasında olumlu veya olumsuz bir ilişki tespit edilmiştir. Literatürdeki çalışmaların bir kısmında da dış borç ekonomik büyüme ilişkisi kısa ve uzun dönemli etkiler gözetilerek incelenmiştir. Ayrıca, nedensellik analizi yapılarak dış borç ve ekonomik büyüme arasındaki ilişkinin yönünün incelendiği çalışmalara da ulaşılmıştır. Gerek yurt içi gerekse yurt dışı çalışmalardan oluşan literatür incelendiğinde, dış borcun ekonomik büyüme üzerindeki hem olumsuz hem de olumlu etkilerine ilişkin kanıtlar sunmasına rağmen, çalışmalarda ortaya çıkan ağırlıklı sonuç dış borçların ekonomik büyüme üzerinde olumsuz etkisi olduğudur. Aşağıda Tablo 2'de Türkiye'ye yönelik farklı dönemleri kapsayan çalışmaların sonuçlarına ilişkin bilgilere yer verilmiştir.

Tablo 2. Ampirik Literatür Özeti (Türkiye'ye İlişkin Çalışmalar)

\begin{tabular}{|c|c|c|}
\hline Yazar(lar) & Dönem / Ülke(ler) & Sonuç \\
\hline Ağır (2016) & 1970-2014 / Türkiye & $\begin{array}{l}\text { Ekonomik büyüme, dış borç artışından negatif } \\
\text { etkilenmiștir. }\end{array}$ \\
\hline Balkanlı (2019) & 1983-2017 / Türkiye & Dıș borçların GSYİH üzerindeki etkisi pozitiftir. \\
\hline Bayır (2020) & 2002Q1-2020Q1 & $\begin{array}{l}\text { Uzun dönemde, dış borçlanmanın ekonomik } \\
\text { büyüme üzerindeki etkisi negatiftir ve dış } \\
\text { borçlanmadan ekonomik büyümeye doğru tek } \\
\text { yönlü nedensellik ilişkisi vardır. }\end{array}$ \\
\hline $\begin{array}{l}\text { Bayrak ve Esen } \\
(2012)\end{array}$ & 1980-2010 / Türkiye & $\begin{array}{l}\text { Uzun vadede diş borçlar ekonomik büyüme } \\
\text { üzerinde etkili olurken, kısa vadede bir etki } \\
\text { görülmemektedir. Ayrıca, kısa vadeli dış borçlar } \\
\text { ekonomik büyümeyi olumsuz etkilerken, uzun } \\
\text { vadeli diş borçların ekonomik büyüme üzerindeki } \\
\text { etkisi olumludur. }\end{array}$ \\
\hline Benli (2020) & 1970-2018 / Türkiye & $\begin{array}{l}\text { Türkiye'de Borç Laffer eğrisi hipotezinin } \\
\text { desteklenmediği, dıs borç yükünün ekonomik } \\
\text { büyüme üzerindeki etkisi negatif bulunmuştur. }\end{array}$ \\
\hline Biçer (2020) & 1970-2017 / Türkiye & $\begin{array}{l}\text { Borç fazlası hipotezinin test edildiği çalışmada, dış } \\
\text { borçların ekonomik büyüme üzerindeki etkisi } \\
\text { negatiftir. }\end{array}$ \\
\hline $\begin{array}{l}\text { Bilginoğlu ve } \\
\text { Aysu (2008) }\end{array}$ & 1968-2005 / Türkiye & $\begin{array}{l}\text { Dış borçlanmanın ekonomik büyüme üzerindeki } \\
\text { etkisi negatiftir. }\end{array}$ \\
\hline $\begin{array}{l}\text { Çiçek vd. } \\
(2010)\end{array}$ & 1990Q1-2009Q3 & $\begin{array}{l}\text { İç borçların ekonomik büyüme üzerindeki etkisi } \\
\text { pozitif iken, dış borçların etkisi negatiftir. }\end{array}$ \\
\hline $\begin{array}{l}\text { Çöğürcü ve } \\
\text { Çoban (2011) }\end{array}$ & 1980-2009 / Türkiye & $\begin{array}{l}\text { Diş borçlar ekonomik büyümeyi negatif } \\
\text { etkilemektedir. }\end{array}$ \\
\hline $\begin{array}{l}\text { Doğan ve } \\
\text { Bilgili (2014) }\end{array}$ & 1974-2019 / Türkiye & $\begin{array}{l}\text { Hem kamu hem de özel sektör dış borcunun } \\
\text { ekonomik büyüme üzerindeki etkisi negatiftir. }\end{array}$ \\
\hline Doruk (2018) & 1970-2014 / Türkiye & $\begin{array}{l}\text { Dış borç ve ekonomik büyüme arasındaki ilişki } \\
\text { negatif yönlüdür. }\end{array}$ \\
\hline $\begin{array}{l}\text { Ela ve Pata } \\
(2020)\end{array}$ & 1987-2017 / Türkiye & $\begin{array}{l}\text { Türkiye'de kamu dış borçları kaynaklı dışlama } \\
\text { etkisi hipotezi ve borç fazlası hipotezi geçerli } \\
\text { değildir. }\end{array}$ \\
\hline
\end{tabular}




\begin{tabular}{|c|c|c|}
\hline $\begin{array}{l}\text { Hotunluoğlu ve } \\
\text { Yavuzer (2020) }\end{array}$ & 2000Q1-2019Q3 / Türkiye & $\begin{array}{l}\text { Dış borç ve ekonomik büyüme arasındaki uzun } \\
\text { dönemli ilişki pozitiftir. }\end{array}$ \\
\hline Karagöl (2002) & 1956-1996 / Türkiye & $\begin{array}{l}\text { Dış borç servisinin kısa dönemde ekonomik } \\
\text { büyüme üzerindeki etkisi negatiftir. Ayrıca diş } \\
\text { borç servisi ve GSMH arasında tek yönlü } \\
\text { nedensellik ilişkisi vardır. }\end{array}$ \\
\hline Özel (2015) & 1970-2013 / Türkiye & $\begin{array}{l}\text { Dış borçların ekonomik büyüme üzerindeki etkisi } \\
\text { negatiftir. }\end{array}$ \\
\hline $\begin{array}{l}\text { Öztürk vd. } \\
\text { (2019) }\end{array}$ & 1970-2016 / Türkiye & $\begin{array}{l}\text { Dış borçların ekonomik büyüme üzerindeki etkisi } \\
\text { pozitiftir. }\end{array}$ \\
\hline $\begin{array}{l}\text { Pata ve Ela } \\
(2020)\end{array}$ & 1987-2017 / Türkiye & $\begin{array}{l}\text { DOLS tahmincisi sonucunda Borç Laffer eğrisinin } \\
\text { Türkiye ekonomisinde geçerli olduğu ve diş borç } \\
\text { stoku/GSMH kritik eşik değerinin } \% 47 \text { oldugu } \\
\text { tespit edilmiştir. }\end{array}$ \\
\hline $\begin{array}{l}\text { Toktaş vd. } \\
(2019)\end{array}$ & 2003Q1-2017Q1 / Türkiye & $\begin{array}{l}\text { Net diş borç stoku ile ekonomik büyüme arasında } \\
\text { nedensellik ilişkisi bulunmuştur. }\end{array}$ \\
\hline $\begin{array}{l}\text { Uysal vd. } \\
\text { (2009) }\end{array}$ & 1965-2007 / Türkiye & $\begin{array}{l}\text { D1ş borcun ekonomik büyüme üzerinde kısa ve } \\
\text { uzun dönemli etkileri negatiftir. }\end{array}$ \\
\hline $\begin{array}{l}\text { Yaraşır } \\
\text { Tülümce ve } \\
\text { Yavuz (2017) }\end{array}$ & 1989-2015 / Türkiye & $\begin{array}{l}\text { Uzun vadeli dış borçlanmanın ekonomik büyüme } \\
\text { üzerindeki etkisi negatiftir. }\end{array}$ \\
\hline Y1ld1z (2019) & 1998Q1-2017Q4 / Türkiye & $\begin{array}{l}\text { Dış borçların ekonomik büyüme üzerindeki etkisi } \\
\text { pozitiftir ve değişkenler arasındaki nedensellik } \\
\text { iliş̧kisi çift yönlüdür. }\end{array}$ \\
\hline
\end{tabular}

Tablo 2'de, dış borçlar ile ekonomik büyüme arasında dışlama etkisi hipotezi ve borç fazlası hipotezini destekleyici nitelikte negatif ilişki bulan çalışmalar arasında; Yaraşır Tülümce ve Yavuz (2017), Çiçek vd. (2010), Uysal vd. (2009), Özel (2015), Karagöl (2002), Doruk (2018), Çögürcü ve Çoban (2011), Bilginoğlu ve Aysu (2008), Biçer (2020), Benli (2020), Doğan ve Bilgili (2014), Bayır (2020) ve Ağır (2016)'ın çalışmaları vardır. Dış borç ve ekonomik büyüme arasında pozitif ilişki bulan ve borçla büyüme modelini destekleyici sonuca ulaşılan çalışmalar; Öztürk vd. (2019), Hotunluoğlu ve Yavuzer (2020), Yıldız (2019), Ela ve Pata (2020), Balkanlı (2019) ve Bayrak ve Esen (2012)'nin çalışmalarıdır. Türkiye ile ilgili Pata ve Ela (2020) çalışmasında dış borcun ekonomik büyümeyi pozitif etkilediği seviyenin sınır düzeyi (eşik değer) tespit edilmiş ve diş borç stoku/GSMH eşik değeri \%47 olarak bulunmuştur. Ayrıca, Yıldız (2019), Bayır (2020) ve Toktaş vd. (2019) çalışmalarında, Türkiye'de dış borç ile ekonomik büyüme arasında nedensellik ilişkisi tespit edilmiştir.

Dış borç ve ekonomik büyüme arasındaki ilişki, farklı ülkeler için dış borç yükünün ekonomik büyüme üzerindeki etkisinin ortaya çıkarılmasını amaçlayan çalışmalarda incelenmiştir. Bu etkinin incelendiği yabancı ülkelerle ilgili ampirik literatürün genel sonuçları, dış borç ve ekonomik büyüme arasındaki üç farklı ilişki türünü göstermiştir. Bunlar, dış borcun ekonomik büyüme üzerindeki etkisinin pozitif, negatif ve doğrusal olmayan bir ilişkiye sahip olabileceğidir. Ayrıca, yurt dışı literatürde dış borcun ekonomik büyüme üzerindeki doğrusal olmayan etkisini borç fazlası hipotezi ve borçla büyüme hipotezini sentezleyerek farklı bir yaklaşımla Borç Laffer Eğrisi ilkeleri doğrultusunda inceleyen ampirik çalışmalar da vardır. Ampirik nitelikteki bu çalışmalarda ülkelerin dış borç eşik düzeylerinin tespiti ve dış borcun ekonomik büyüme üzerindeki olumsuz etkisinin hangi seviyelerden sonra oluşabileceği araştırılmıştır. Tablo 3 'te, dış borç ve ekonomik büyüme ilişkisinin incelendiği yabancı ülkelere yönelik çalışmalara yer verilmiştir. 
Tablo 3. Ampirik Literatür Özeti (Yabancı Ülkelere İlişkin Çalışmalar)

\begin{tabular}{|c|c|c|}
\hline Yazar(lar) & Dönem / Ülke(ler) & Sonuç \\
\hline $\begin{array}{l}\text { Akçay ve Çelik } \\
(2020)\end{array}$ & $\begin{array}{l}\text { 1970-2017 / ECOWAS } \\
\text { Ülkeleri (12 Ülke) }\end{array}$ & Dış borçlar sürdürülebilir nitelikte değildir. \\
\hline $\begin{array}{l}\text { Ali ve Mustafa } \\
(2012)\end{array}$ & 1970-2010 / Pakistan & $\begin{array}{l}\text { Dış borcun ekonomik büyüme üzerinde olumsuz } \\
\text { bir etkisi olduğunu, yüksek dış borcun ekonomik } \\
\text { büyümeyi caydırdığını göstermiştir. }\end{array}$ \\
\hline $\begin{array}{l}\text { Anning vd. } \\
(2016)\end{array}$ & 1990-2015 / Gana & $\begin{array}{l}\text { Diş borç ve iç borç yükünün ekonomik büyüme } \\
\text { üzerindeki etkisi negatiftir. }\end{array}$ \\
\hline $\begin{array}{l}\text { Bakar ve } \\
\text { Hassan (2008) }\end{array}$ & 1970-2005 / Malezya & $\begin{array}{l}\text { Uzun vadede toplam dış borç yükündeki } \% 1 \text { 'lik } \\
\text { artış, ekonomik büyümeyi } \% 1.29 \text { artırmaktadır. } \\
\text { İlişki pozitiftir. }\end{array}$ \\
\hline $\begin{array}{l}\text { Cebeci Mazlum } \\
(2020)\end{array}$ & $\begin{array}{l}\text { 1990-2016 / Latin Amerika } \\
\text { Ülkeleri (16 Ülke) }\end{array}$ & $\begin{array}{l}\text { Dış borç ve ekonomik büyüme arasında ülkelere } \\
\text { göre farklılık gösteren nedensellik ilişkileri tespit } \\
\text { edilmiştir. }\end{array}$ \\
\hline $\begin{array}{l}\text { Dao ve Oanh } \\
\text { (2017) }\end{array}$ & 2000Q1-2012Q4 / Vietnam & $\begin{array}{l}\text { Laffer Eğrisi analizi sonucunda dış borç ile } \\
\text { ekonomik büyüme arasında doğrusal olmayan } \\
\text { (ters U şeklinde) ilişkinin varlığını } \% 28 \text { eşik } \\
\text { seviyesi ile tespit edilmiştir. Ayrıca çalışma, eşik } \\
\text { sonrasında diş borcun ekonomik büyümeye etki } \\
\text { düzeyi de ölçülmüştür. }\end{array}$ \\
\hline Daud, (2020) & $\begin{array}{l}2005-2016 \text { / Gelişmekte olan } \\
53 \text { ülke }\end{array}$ & $\begin{array}{l}\text { Yüksek dış borçluluk düzeyinin (Dış Borç } \\
\text { Stoku/GSMH rasyosu \% } 46.56 \text { üstü) ekonomik } \\
\text { büyüme üzerindeki etkisi negatiftir. Ancak } \\
\text { kurumsal kalitedeki iyileşme bu olumsuz etkiyi } \\
\text { azaltmaktadır. }\end{array}$ \\
\hline $\begin{array}{l}\text { Dey ve Tareque } \\
(2020)\end{array}$ & 1980-2017 / Bangladeş & $\begin{array}{l}\text { Çalışma sonuçları, dış borcun GSYİH büyümesi } \\
\text { üzerindeki olumsuz etkisini ortaya koymaktadır. }\end{array}$ \\
\hline $\begin{array}{l}\text { Ehikioya vd. } \\
\text { (2020) }\end{array}$ & $\begin{array}{l}\text { 2001-2018 / } 43 \text { Afrika } \\
\text { Ülkesi }\end{array}$ & $\begin{array}{l}\text { Belirli bir düzeyin üzerindeki dış borçlanmanın } \\
\text { uzun vadede ekonomik büyüme üzerindeki etkisi } \\
\text { olumsuzdur. }\end{array}$ \\
\hline Felix (2020) & $\begin{array}{l}\text { 1990-2016 / } 15 \text { ECOWAS } \\
\text { Ülkesi }\end{array}$ & $\begin{array}{l}\text { Dış borç ve ekonomik büyüme ilişkisi kısa ve uzun } \\
\text { vadede farklı oranda tespit ettiği eşik değere kadar } \\
\text { pozitiftir. }\end{array}$ \\
\hline $\begin{array}{l}\text { Ganiev vd. } \\
(2020)\end{array}$ & $\begin{array}{l}\text { 2000Q1-2007Q3 / } \\
\text { Kirgizistan }\end{array}$ & $\begin{array}{l}\text { Uzun dönemde kamu dış borçları, cari transferler, } \\
\text { özel sektör borçları ve doğrudan yabancı } \\
\text { yatırımların ekonomik büyüme üzerindeki etkisi } \\
\text { pozitiftir. }\end{array}$ \\
\hline Gül vd. (2012) & $\begin{array}{l}\text { 1994-2010 / } 7 \text { Ülke (Türkiye } \\
\text { ve } 6 \text { Orta Asya Türk } \\
\text { Devleti) }\end{array}$ & $\begin{array}{l}\text { Dış borçlardan ekonomik büyüme doğru tek yönlü } \\
\text { nedensellik ilişkisi vardır. }\end{array}$ \\
\hline $\begin{array}{l}\text { Hussain vd. } \\
\text { (2015) }\end{array}$ & $\begin{array}{l}\text { 1995-2012 / } 48 \text { Sahra-alt1 } \\
\text { Afrika Ülkesi }\end{array}$ & $\begin{array}{l}\text { Dış borç ve ekonomik büyüme arasındaki ilişki } \\
\text { negatiftir. Araştırma sonuçları dışlama hipotezi ve } \\
\text { borç Laffer eğrisi yaklaşıların doğrulamıştır. }\end{array}$ \\
\hline $\begin{array}{l}\text { Jilenga vd. } \\
(2016)\end{array}$ & 1971-2011 / Tanzanya & $\begin{array}{l}\text { Dış borçların ekonomik büyüme üzerinde uzun } \\
\text { dönemli etkisi pozitif, kısa dönemde ise dış borç } \\
\text { ve ekonomik büyüme arasında nedensellik ilişsisi } \\
\text { yoktur. }\end{array}$ \\
\hline $\begin{array}{l}\text { Kazakova ve } \\
\text { Inaba (2018) }\end{array}$ & $\begin{array}{l}\text { 1981-2015 / } 117 \text { Gelişmekte } \\
\text { Olan ve Yükselen Ülke }\end{array}$ & $\begin{array}{l}\text { Araştırma sonucu, dış borç ile ekonomik büyüme } \\
\text { arasında doğrusal olmayan bir ilişkiyi ortaya } \\
\text { çıkarmıştır. Gelişmekte olan ülkelerde ekonomik }\end{array}$ \\
\hline
\end{tabular}




\begin{tabular}{|c|c|c|}
\hline & & $\begin{array}{l}\text { bir yavaşlamaya veya büyüme hızında azalmaya } \\
\text { yol açan dış borçlanmaya ilişkin eşik değer } \\
\text { GSYİH'nın \%61.3'ü, kamu ve kamu garantili dış } \\
\text { borç için ise eşik değer GSYİH'nın yüzde } 30 \text { 'u } \\
\text { olarak bulunmuştur. }\end{array}$ \\
\hline $\begin{array}{l}\text { Kharusi ve Ada } \\
\text { (2018) }\end{array}$ & 1990-2015 / Umman & $\begin{array}{l}\text { Diş borçlar ekonomik büyümeyi negatif } \\
\text { etkilemektedir. }\end{array}$ \\
\hline $\begin{array}{l}\text { Lin ve Sosin } \\
(2001)\end{array}$ & $\begin{array}{l}\text { 1970-1992 / } 77 \text { Ülke } \\
\text { (18 Sanayileşmiş, } 18 \text { Latin } \\
\text { Amerika, 24 Afrika, } 17 \text { Asya } \\
\text { ve diğer GOÜ) }\end{array}$ & $\begin{array}{l}\text { Afrika ülkelerinde dış borç ve kişi başına GSYİH } \\
\text { artış oranı arasındaki ilişki negatiftir. Diğer } \\
\text { ülkelerde bu ilişki pozitiftir, ancak istatistiksel } \\
\text { olarak anlamsızdır. }\end{array}$ \\
\hline N'Zue (2020) & $\begin{array}{l}\text { 1990-2016 / ECOWAS } \\
\text { Ülkeleri }\end{array}$ & $\begin{array}{l}\text { Dış borç eşik değere kadar ekonomik büyüme } \\
\text { üzerinde olumlu bir etkiye sahiptir. ECOWAS } \\
\text { ülkelerinde eşik değer, kısa vadede } \% 45 \text {, uzun } \\
\text { vadede ise } \% 42.5 \text { olarak bulunmuştur. }\end{array}$ \\
\hline Nath (2020) & 1970-2018 / Hindistan & $\begin{array}{l}\text { D1ş borç servisi diş borcun göstergesi olarak } \\
\text { değerlendirildiğinde diş borcun ekonomik büyüme } \\
\text { üzerinde uzun vadeli etkisi pozitiftir }\end{array}$ \\
\hline $\begin{array}{l}\text { Ndoricimpa } \\
(2017)\end{array}$ & $\begin{array}{l}\text { 1980-2010 / } 39 \text { Afrika } \\
\text { Ülkesi }\end{array}$ & $\begin{array}{l}\% 92 \text { ile } \% 102 \text { arasında bir borç eşiği tahmin } \\
\text { edilmiş ve düşük borç büyümeyi artırıcı veya nötr } \\
\text { olsa da yüksek borcun, dikkate alınan tüm } \\
\text { durumlar için büyümeye sürekli olarak zararlı } \\
\text { olduğunu göstermiştir }\end{array}$ \\
\hline $\begin{array}{l}\text { Ndoricimpa } \\
(2020)\end{array}$ & $\begin{array}{l}\text { 1980-2012 / } 39 \text { Afrika } \\
\text { Ülkesi }\end{array}$ & $\begin{array}{l}\text { Tüm ülkeler için } \% 62 \text { ile } \% 66 \text { arasında bir borç } \\
\text { eşiği tahmini ve yüksek kamu borcunun büyümeye } \\
\text { zararlı olduğu tespit edilmiştir. }\end{array}$ \\
\hline $\begin{array}{l}\text { Nounamo vd. } \\
(2020)\end{array}$ & 1985-2015 / 10 CFA Ülkesi & $\begin{array}{l}\text { D1ş borç ve ekonomik büyüme ilişkisi negatif } \\
\text { yönlüdür. }\end{array}$ \\
\hline Ohiomu (2020) & 1984-2018 / Nijerya & $\begin{array}{l}\text { Dış borçların özel kesim yatırımları üzerinde } \\
\text { dışlama etkisi ve ekonomik büyüme üzerinde } \\
\text { negatif etkisi tespit edilmiştir. }\end{array}$ \\
\hline Oluseyi (2013) & $\begin{array}{l}\text { 1971-2012 / Batı Afrika } \\
\text { Ülkeleri }\end{array}$ & $\begin{array}{l}\text { İlgili ülkelerin ekonomilerinde diş borç ile } \\
\text { ekonomik büyüme arasında negatif bir ilişki } \\
\text { vardır. }\end{array}$ \\
\hline $\begin{array}{l}\text { Omodero ve } \\
\text { Alpheaus } \\
(2019)\end{array}$ & 1997-2017 / Nijerya & $\begin{array}{l}\text { Ekonomik büyüme üzerinde dış borcun etkisi } \\
\text { negatif, dış borç servisinin etkisi ise pozitiftir. }\end{array}$ \\
\hline $\begin{array}{l}\text { Pattillo vd. } \\
\text { (2011) }\end{array}$ & $\begin{array}{l}\text { 1969-1998 / } 93 \text { Geliş̧mekte } \\
\text { Olan Ülke }\end{array}$ & $\begin{array}{l}\text { Dış borç stoku/GSMH kritik eşik değerinin \%35- } \\
40 \text { düzeyini aştığında ekonomik büyüme } \\
\text { üzerindeki etkisi negatiftir. }\end{array}$ \\
\hline $\begin{array}{l}\text { Presbitero } \\
(2006)\end{array}$ & $\begin{array}{l}\text { 1977-2002 / } 69 \text { Geliş̧mekte } \\
\text { Olan Yoksul Ülkeler }\end{array}$ & $\begin{array}{l}\text { Dış borçlanma ve ekonomik büyüme ile dış borç } \\
\text { servisi ve yatırım arasında negatif ilişki } \\
\text { bulunmuştur. }\end{array}$ \\
\hline Shabbir (2013) & $\begin{array}{l}\text { 1976-2011 / } 76 \text { Gelişmekte } \\
\text { Olan Ülke }\end{array}$ & $\begin{array}{l}\text { D1ş borçtaki artışın dış borç ödeme gücünü } \\
\text { azalttığı, ekonomik büyümeyi olumsuz etkilediği } \\
\text { ve özel kesim sabit sermaye oluşumunda bir } \\
\text { bozulmaya neden olduğu gözlemlenmiştir. }\end{array}$ \\
\hline $\begin{array}{l}\text { Shkolnyk ve } \\
\text { Koilo (2018) }\end{array}$ & $\begin{array}{l}\text { 2006-2016 / Ukrayna ve } 10 \\
\text { Gelişmekte Olan Ülke }\end{array}$ & $\begin{array}{l}\text { Makroekonomik istikrarsıllıkla bağlantıli olarak } \\
\text { yüksek dış borç seviyesinin bu ülkelerde } \\
\text { ekonomik büyümeyi olumsuz etkilediği tespit } \\
\text { edilmiştir. }\end{array}$ \\
\hline
\end{tabular}




\begin{tabular}{|c|c|c|}
\hline $\begin{array}{l}\text { Silva } \\
(2020)\end{array}$ & 1999-2019 / Portekiz & $\begin{array}{l}\text { Kamu ve özel sektör dış borcu kamu yatırımları } \\
\text { üzerinde pozitif, özel sektör dış borcu özel } \\
\text { yatırımlar üzerinde negatif etkide bulunmuştur. } \\
\text { Dış borçlar, ekonomik büyümeyi olumlu şekilde } \\
\text { etkileyecek nitelikte kullanılmamıştır. }\end{array}$ \\
\hline Tuffour (2012a) & 1970-2009 / Gana & $\begin{array}{l}\text { Dış borç ve ekonomik büyüme arasında ters-U } \\
\text { ilişkisi vardır. Borç Laffer eğrisi hipotezi } \\
\text { geçerlidir. }\end{array}$ \\
\hline $\begin{array}{l}\text { Uzun vd. } \\
\text { (2012) }\end{array}$ & $\begin{array}{l}\text { 1991-2009 / } 19 \text { Geçiş } \\
\text { Ekonomisi Ülkesi }\end{array}$ & $\begin{array}{l}\text { Uzun vadede ülkelerin borç ve büyüme oranları } \\
\text { arasında pozitif bir ilişki bulunmuş ve Geçiş } \\
\text { Ekonomisi ülkeleri hala borç Laffer eğrisinin } \\
\text { pozitif eğimli tarafındadır. }\end{array}$ \\
\hline $\begin{array}{l}\text { Zhang vd. } \\
(2020)\end{array}$ & $\begin{array}{l}\text { 1995-2019 / } 18 \text { Seçilmiş } \\
\text { Gelişmekte Olan Asya ve } \\
\text { Geçiş Ekonomisi Ülkeleri }\end{array}$ & $\begin{array}{l}\text { Kısa ve uzun dönemde dış borç ve ekonomik } \\
\text { büyüme arasında çift yönlü nedensellik ilişkisi } \\
\text { vardır. }\end{array}$ \\
\hline
\end{tabular}

Yabancı ülkelere ilişkin yapılmış olan çalışmalardan; Tuffour (2012a), Shkolnyk ve Koilo (2018), Shabbir (2013), Presbitero (2006), Omodero ve Alpheaus (2019), Oluseyi (2013), Ohiomu (2020), Nounamo vd. (2020), Lin ve Sosin (2001), Kharusi ve Ada (2018), Dey ve Tareque (2020), Hussain vd. (2015), Ehikioya vd. (2020), Daud, (2020), Anning vd. (2016), Ali ve Mustafa (2012), Akçay ve Çelik (2020) dış borçlar ile ekonomik büyüme arasındaki ilişkiyi dışlama etkisi hipotezi ve borç fazlası hipotezini destekleyici nitelikte negatif olarak tespit etmişlerdir. Silva (2020) ise özel sektör dış borçları ile özel yatırımlar arasındaki ilişkiyi negatif olarak bulmuştur. Diğer yandan Uzun vd. (2012), Nath (2020), Jilenga vd. (2016), Ganiev vd. (2020), Felix (2020), Bakar ve Hassan (2008)' in çalışmalarında dış borçlar ile ekonomik büyüme arasındaki ilişki borçla büyüme modelini destekleyici nitelikte pozitif olarak tespit edilmiştir. Omodero ve Alpheaus (2019) çalışmalarında dış borç servisinin ekonomik büyüme üzerindeki etkisini pozitif olarak tespit ederken Silva (2020) kamu ve özel sektör dış borcunun kamu yatırımları üzerindeki etkisini pozitif olarak tespit etmiştir. Bazı çalışmalarda ise dış borcun ekonomik büyümeyi pozitif etkilediği seviyenin sınır düzeyi (eşik değer) ülkelere göre tespit edilmiştir (Pattillo vd., 2011; Ndoricimpa, 2017; Ndoricimpa, 2020; N'Zue, 2020; Kazakova ve Inaba, 2018; Dao ve Oanh, 2011). Söz konusu çalışmalarda ülkelere göre farklılık gösteren eşik değerlere ulaşılmıştır. Dış borç ile ekonomik büyüme arasındaki nedensellik ilişkisinin incelendiği ve tek yönlü veya çift yönlü nedensellik ilişkisinin bulunduğu çalışmalar ise; Zhang vd. (2020), Gül vd. (2012) ve Cebeci Mazlum (2020)'nin çalışmalarıdır.

\section{ANALIZ VE BULGULAR}

Türkiye ve BRICS (Brezilya, Rusya, Hindistan, Çin, Güney Afrika) ülkelerinde dış borç bileşenlerinin ekonomik büyüme üzerindeki etkisini analiz etmek amaciyla uzun dönemli bir tahmin yöntemi kullanılmıştır. Araştırmanın analiz dönemi 1997-2019 yıllarını kapsamaktadır ve belirtilen döneme ilişkin yıllık veriler kullanılmıştır. Kullanılan değişkenlere ait bilgiler Tablo 4'te verilmiştir. $E B$ reel ekonomik büyüme oranını, $T D B$ ülkelerin toplam dış borç düzeylerinin GSYİH'ya oranını göstermektedir. Dış borç bileşenlerinin ekonomik büyüme üzerindeki etkisini görebilmek amacıyla toplam kamu dış borcu $(K D B)$ ve özel kesim diş borcu $(O ̈ D B)$ değişkeleri ayrı modellerde tahmin edilmiştir. $K D B$ ülkelerin toplam kamu dış borcunun GSYİH'ya oranını, $O ̈ D B$ ise özel kesim dış borç düzeyinin GSYİH'ya oranlanmasıyla elde edilmiştir. Araştırmada kullanılan tüm değişkenler Dünya Bankası (WB) veri tabanından derlenmiştir. Tahmin edilecek modeller Silva (2020) ile Bayrak ve Esen (2012)'nin çalışmaları 
dikkate alınarak oluşturulmuştur. Her iki çalışma dış borçların bileşenlerini analizlere dâhil etmeleri yönüyle literatürdeki diğer çalışmalardan ayrışmaktadır. Silva (2020), kamu ve özel sektör dış borcunun kamu yatırımları, özel yatırımlar ve ekonomik büyüme üzerindeki etkilerini; Bayrak ve Esen (2012) ise diş borçlanmayı bileşenleri itibariyle (kamu dış borcu, özel sektör dış borcu, kısa vadeli dış borçlar ve uzun vadeli dış borçlar) ayrıştırarak ekonomik büyüme üzerindeki etkilerini analiz etmiştir. Tahminler Stata 12 ve Gauss 10 programları kullanılarak gerçekleştirilmiştir.

Tablo 4. Değişkenlere Ait Bilgiler

\begin{tabular}{lll}
\hline Değişsen & Açılklama & Kaynak \\
\hline EB & GSYİH büyüme oranı (\%) & Dünya Bankas1 \\
TDB & Toplam diş borç (\%GSYİH) & Dünya Bankas1 \\
KDB & Toplam kamu diş borcu (\%GSYIH) & Dünya Bankas1 \\
ÖDB & Toplam özel sektör dış borcu (\%GSYİH) & Dünya Bankas1 \\
\hline
\end{tabular}

Dış borç bileşenlerinin Türkiye ve BRICS ülkelerinde ekonomik büyüme üzerinde etkisini tahmin edebilmek amacıyla panel veri analizi kullanılmıştır. Analizde kullanılan değişkenlere ait istatistikler Tablo 5'te özetlenmiştir.

Tablo 5. Tanımlayıcı İstatistikler

\begin{tabular}{lcccc}
\hline & EB & TDB & KDB & ÖDB \\
\hline Ortalama & 4.682 & 0.218 & 0.115 & 0.103 \\
Medyan & 4.992 & 0.217 & 0.102 & 0.097 \\
Maximum & 14.231 & 0.721 & 0.606 & 0.265 \\
Minimum & -7.800 & 0.036 & 0.013 & 0.002 \\
Standart Sapma & 3.843 & 0.113 & 0.081 & 0.059 \\
Çarpiklık & -0.518 & 0.722 & 2.339 & 0.320 \\
Basıklık & 3.473 & 4.573 & 12.831 & 2.510 \\
Jarque-Bera & 7.471 & 26.231 & 681.584 & 3.738 \\
Gözlem & 138 & 138 & 138 & 138 \\
\hline
\end{tabular}

\section{Modeller}

$\mathrm{EB}_{i t}=\beta_{0}+\beta_{1} \mathrm{TDB}_{i t}+e_{i t}$

$\mathrm{EB}_{i t}=\beta_{0}+\beta_{1} \mathrm{KDB}_{i t}+e_{i t}$

$\mathrm{EB}_{i t}=\beta_{0}+\beta_{1} \mathrm{ODDB}_{i t}+e_{i t}$

$i=1, \ldots \ldots ., 6$ (Brezilya, Rusya, Hindistan, Çin, Güney Afrika, Türkiye)

$t=1, \ldots \ldots .23$ (1997-2019).

Değişkenlerin yatay kesit bağımlılık test sonuçları Tablo 6'da gösterilmektedir. Test sonuçlarına göre modellerde kullanılan değişkenlerin tamamının yatay kesit bağımlılığının olduğu görülmektedir. Dış borç bileşenlerinin ekonomik büyüme üzerindeki etkisini tahmin etmeden önce tahmin modellerinde kullanılan değişkenlerin durağanlıkları incelenmiştir. Değişkenlerin durağanlık derecelerinin tespitinde Pesaran (2007) CADF Testi kullanılmıştır. Seriler arasındaki yatay kesit bağımlılığını dikkate alan CADF Testi sonuçları Tablo 6'da özetlenmiştir.

Tablo 6. Birim Kök ve Yatay Kesit Bağımlılığı Test Sonuçları

\begin{tabular}{llllllll}
\hline & & $t$-bar & $c v 10$ & $c v 5$ & $c v 10$ & Z[t-bar] & $P$-value \\
\hline EB & Sabitli & -3.063 & -2.730 & -2.860 & -3.100 & -1.983 & 0.024 \\
EB & Sabitli ve Trendli & -1.914 & -2.730 & -2.860 & -3.100 & 1.044 & 0.852 \\
$\Delta$ EB & Sabitli & -3.257 & -2.210 & -2.330 & -2.570 & -3.781 & 0.000 \\
$\Delta$ EB & Sabitli ve Trendli & -2.966 & -2.730 & -2.860 & -3.100 & -1.727 & 0.042
\end{tabular}




\begin{tabular}{|c|c|c|c|c|c|c|c|}
\hline TDB & Sabitli & -2.584 & -2.210 & -2.330 & -2.570 & -2.082 & 0.019 \\
\hline TDB & Sabitli ve Trendli & -3.111 & -2.730 & -2.860 & -3.100 & -2.110 & 0.017 \\
\hline$\Delta \mathrm{TDB}$ & Sabitli & -3.267 & -2.210 & -2.330 & -2.570 & -3.807 & 0.000 \\
\hline$\Delta \mathrm{TDB}$ & Sabitli ve Trendli & -3.523 & -2.730 & -2.860 & -3.100 & -3.195 & 0.001 \\
\hline KDB & Sabitli & -1.959 & -2.210 & -2.330 & -2.570 & -0.504 & 0.307 \\
\hline KDB & Sabitli ve Trendli & -2.319 & -2.730 & -2.860 & -3.100 & -0.025 & 0.490 \\
\hline$\Delta \mathrm{KDB}$ & Sabitli & -2.930 & -2.210 & -2.330 & -2.570 & -2.955 & 0.002 \\
\hline$\triangle \mathrm{KDB}$ & Sabitli ve Trendli & -3.063 & -2.730 & -2.860 & -3.100 & -1.983 & 0.024 \\
\hline ÖDB & Sabitli & -2.596 & -2.210 & -2.330 & -2.570 & -2.110 & 0.017 \\
\hline ÖDB & Sabitli ve Trendli & -2.171 & -2.730 & -2.860 & -3.100 & 0.366 & 0.643 \\
\hline$\Delta$ ÖDB & Sabitli & -2.961 & -2.210 & -2.330 & -2.570 & -3.033 & 0.001 \\
\hline$\Delta$ ÖDB & Sabitli ve Trendli & -3.242 & -2.730 & -2.860 & -3.100 & -2.455 & 0.007 \\
\hline \multicolumn{8}{|c|}{ Yatay Kesit Bağımlılı̆̆ı Test Sonuçları } \\
\hline & CDLM $_{1}$ & \multicolumn{2}{|c|}{$\mathrm{CDLM}_{2}$} & \multicolumn{2}{|c|}{ CDLM } & \multicolumn{2}{|c|}{ CDLM $_{\text {adj }}$} \\
\hline EB & $81.955(0.000)$ & \multicolumn{2}{|c|}{$11.128(0.000)$} & \multicolumn{2}{|c|}{$10.992(0.000)$} & \multicolumn{2}{|c|}{$6.917(0.000)$} \\
\hline TDB & $94.370(0.000)$ & \multicolumn{2}{|c|}{$13.395(0.000)$} & \multicolumn{2}{|c|}{$13.259(0.000)$} & \multicolumn{2}{|c|}{$5.281(0.000)$} \\
\hline KDB & $159.484(0.000)$ & \multicolumn{2}{|c|}{$25.283(0.000)$} & \multicolumn{2}{|c|}{$25.147(0.000)$} & \multicolumn{2}{|c|}{$8.614(0.000)$} \\
\hline ÖDB & $102.991(0.000)$ & \multicolumn{2}{|c|}{$14.969(0.000)$} & \multicolumn{2}{|c|}{$14.833(0.000)$} & \multicolumn{2}{|c|}{$8.595(0.000)$} \\
\hline
\end{tabular}

Birim kök test sonuçları değişkenlerin tümünün \%1 anlamlılık düzeyinde birinci farklarında durağan hale geldiklerini göstermektedir. Dış borç bileşenleri ve ekonomik büyüme arasındaki uzun dönemli ilişkinin varlığını araştırmak amacıyla eşbütünleşme testi yapılmıştır. Eşbütünleşme testi yapılmadan önce oluşturulan modellerin yatay kesit bağımlık test sonuçları Tablo 7'de gösterilmektedir. Test sonuçlarına göre oluşturulan tüm modellerde yatay kesit bağımlılığı sorunu olduğu sonucuna ulaşılmıştır. Bu nedenle yatay kesit bağımlılığının olması veya olmaması ve eşbütünleşme eğim katsayılarının hem homojen hem de heterojen olması durumlarında kullanılabilen Westerlund (2008) Eşbütünleşme testi modellerin tahmininde tercih edilmiştir. Eşbütünleşme test sonuçlarına göre, tahmin edilen tüm modellerde $\mathrm{Gt}, \mathrm{Ga}, \mathrm{Pt}$ ve $\mathrm{Pa}$ istatistiklerinin tamamında eşbütünleşme ilişkisinin olmadığını ifade eden $\mathrm{H}_{0}$ hipotezi reddedilmekte ve değişkenler arasında uzun dönemde eşbütünleşme ilişkisi olduğuna karar verilmektedir. Eşbütünleşme testi sonuçları Tablo 7'de özetlenmiştir.

Tablo 7. Eşbütünleșme ve Model Yatay Kesit Bağımlılığı Testi Sonuçları

\begin{tabular}{|c|c|c|c|c|c|c|}
\hline \multicolumn{7}{|c|}{ Bağımlı Değişken: EB } \\
\hline $\begin{array}{l}\text { Bağımsız } \\
\text { Değișken }\end{array}$ & İstatistik & Değer & Z-Değeri & Olasilık & $\begin{array}{l}\text { Olasılık } \\
\text { (Bootstrap) }\end{array}$ & $\begin{array}{l}\text { Model Yatay } \\
\text { Kesit Bağımlılı̆̆l }\end{array}$ \\
\hline \multirow{4}{*}{ TDB } & Gt & -2.342 & -3.216 & 0.001 & 0.000 & CDLM $_{\text {adj }}$ \\
\hline & $\mathrm{Ga}$ & -9.576 & -3.109 & 0.001 & 0.000 & $9.886(0.000)$ \\
\hline & $\mathrm{Pt}$ & -5.093 & -3.292 & 0.001 & 0.000 & $\mathrm{CDLM}_{1}$ \\
\hline & $\mathrm{Pa}$ & -8.417 & -6.253 & 0.000 & 0.000 & $68.023(0.000)$ \\
\hline \multirow{4}{*}{ KDB } & $\mathrm{Gt}$ & -2.370 & -3.282 & 0.001 & 0.000 & CDLMadj $_{\text {adj }}$ \\
\hline & $\mathrm{Ga}$ & -9.069 & -2.836 & 0.002 & 0.000 & $11.628(0.000)$ \\
\hline & $\mathrm{Pt}$ & -6.064 & -4.124 & 0.000 & 0.000 & $\mathrm{CDLM}_{1}$ \\
\hline & $\mathrm{Pa}$ & -9.520 & -7.186 & 0.000 & 0.000 & $72.681(0.000)$ \\
\hline \multirow{4}{*}{ ÖDB } & $\mathrm{Gt}$ & -2.054 & -2.537 & 0.006 & 0.020 & $\mathrm{CDLM}_{\mathrm{adj}}$ \\
\hline & $\mathrm{Ga}$ & -7.808 & -2.157 & 0.016 & 0.060 & $11.544(0.000)$ \\
\hline & $\mathrm{Pt}$ & -4.571 & -2.845 & 0.002 & 0.000 & $\mathrm{CDLM}_{1}$ \\
\hline & $\mathrm{Pa}$ & -7.898 & -5.814 & 0.000 & 0.000 & $70.842(0.000)$ \\
\hline
\end{tabular}

Eşbütünleşme testi sonuçları, BRICS-T ülkelerinde 1997-2019 yılları arasında toplam dış borç düzeyi (TDB), kamu dış borcu (KDB) ve özel sektör dış borcunun (ÖDB) ekonomik büyüme 854 
ile uzun dönemde bir ilişki içerisinde olduğunu göstermektedir. Tahmin edilen modellerde eşbütünleşme ilişkisi tespit ettikten sonra, eşbütünleşme katsayılarının tahmini gerçekleştirilmiştir. Panel ARDL yönteminde tahmin yöntemleri Havuzlanmış Ortalama Grup (PMG), Havuzlanmış Grup Tahmincisi (MGE) ve Dinamik Sabit Etkiler Tahmincisi (DFE) ile gerçekleştirilmektedir. Panel ARDL tahmininde, ilgili modeller arasında seçim yapmak için literatürde sıkça kullanılan Hausman testi yapılmıştır. Tablo 8'deki Hausman testi sonuçlarına göre, tahmin edilen tüm modellerde PMG tahmincisinin etkin ve tutarlı olduğu sonucuna varılmıştır. Panel ARDL yöntemine dayalı PMG tahmincisine dayalı dış borç bileşenleri ve ekonomik büyüme arasındaki uzun ve kısa dönemli katsayılar Tablo 8'de sunulmuştur. Tablo 8'de gösterilen Model 1 toplam dış borcun, Model 2 kamu dış borcunun, Model 3 ise özel sektör diş borcunun ekonomik büyüme üzerindeki etkisini tahmin edebilmek amaciyla oluşturulmuştur.

Tablo 8. Panel ARDL Tahmin Sonuçları (PMG)

\begin{tabular}{|c|c|c|c|c|c|}
\hline \multicolumn{6}{|c|}{ Bağımlı Değişken: EB } \\
\hline Model 1 & & Model 2 & & Model 3 & \\
\hline Uzun Dönem & & Uzun Dönem & & Uzun Dönem & \\
\hline TDB & $-1.733^{* *}$ & $\mathrm{KDB}$ & $-1.194^{* * *}$ & ÖDB & $-2.245^{* * *}$ \\
\hline$\left(\varphi_{i}\right)$ & $-0.791^{* * * *}$ & $\left(\varphi_{i}\right)$ & $-0.606^{* * * *}$ & $\left(\varphi_{i}\right)$ & $-0.483^{* * * *}$ \\
\hline Kısa Dönem & & Klsa Dönem & & Kısa Dönem & \\
\hline$\Delta \mathrm{TDB}$ & $-8.441^{* * *}$ & $\Delta \mathrm{KDB}$ & $-7.876^{* * *}$ & $\Delta$ ÖDB & $-3.750^{* * *}$ \\
\hline Hausman Testi & $0.94(0.12)$ & & $0.85(0.42)$ & & $0.14(0.65)$ \\
\hline
\end{tabular}

Tablo 8, Panel ARDL yöntemine dayalı tüm modellere ait panel genel bulgularını göstermektedir. Her üç modelde de hata düzeltme katsayısının negatif ve istatistiksel olarak anlamlı olması toplam dış borç, kamu diş borcu ve özel sektör dış borcu değişkenleri ile ekonomik büyüme arasındaki ilişkinin tahmin edildiği modellerde hata düzeltme mekanizmasının çalıştığını (kısa dönemde ortaya çıkan bir şokla iki değişken arasındaki dengeden uzaklaşan ilişkinin uzun dönemde dengeye yöneldiğini) ifade etmektedir. Hata düzeltme katsayılarını değerlendirirsek, toplam dış borç değişkeninin kullanıldığı modelde, kısa dönemli dengeden sapma oranının ilk dönemde \%79'unun tekrar dengeye doğru gideceğine işaret etmektedir. Aynı modelde, uzun ve kısa dönem katsayılarına bakıldığında, toplam dış borcun (TDB) ekonomik büyüme (EB) üzerinde negatif yönlü bir etkiye sahip olduğu tespit edilmiştir. Uzun dönemde, dış borcun GSYİH oranındaki \%1'lik bir artış ekonomik büyümede \%1.73'lik bir düşüşe neden olmaktadır. Benzer yönlü negatif etki kısa dönemde de etkindir. Katsayıların büyüklüğüne göre değerlendirildiğinde, dış borçlanmanın ekonomik büyüme üzerindeki negatif etkisi kısa dönemde uzun döneme göre daha büyüktür. Kısa dönemde toplam dış borç seviyesinin ekonomik büyüme üzerindeki etki oranı yaklaşık $\% 8.44$ civarındadır. Bu sonuç, toplam dış borçların kısa dönemde ekonomik büyüme üzerinde uzun dönemden yaklaşık 7 kat daha fazla negatif etkide bulunduğunu göstermektedir.

Analiz sonuçları kamu dış borcu ve özel sektör dış borcunun da ekonomik büyüme üzerindeki etkisinin negatif ve istatistiksel olarak anlamlı olduğunu göstermiştir. Kamu diş borcundaki (KDB) \%1'lik bir artı̧̧ ekonomik büyümeyi uzun dönemde \%1.19, kısa dönemde ise \%7.86 oranında azaltmaktadır. Kamu dış borçları açısından kısa dönemdeki negatif etki uzun dönemdeki negatif etkiden yaklaşık 7 kat daha fazladır. Bu sonuç, toplam dış borca benzer şekilde kamu dış borcunun kısa dönemde ekonomik büyüme üzerinde daha fazla negatif yönde etkin olduğunu ortaya koymaktadır. Özel sektör dış borcunun (ÖDB) ekonomik büyüme 
üzerindeki hem kısa dönem hem de uzun dönemdeki etkisi negatif ve anlamlıdır. Özel sektör dış borcundaki \%1'lik bir artış ekonomik büyümeyi uzun dönemde $\% 2.24$, kısa dönemde ise \%3.75 oranında azaltmaktadır. Özel sektör dış borcunun kısa ve uzun dönemdeki negatif etkisi diğer borç türlerine göre değerlendirildiğinde birbirlerine daha yakın oldukları görülmektedir. Fakat tüm dış borç bileşenleri birlikte değerlendirildiğinde özel sektör dış borçlarının ekonomik büyüme üzerindeki etkisinin diğer borç türlerine göre en fazla olduğu görülmektedir. $\mathrm{Bu}$ anlamda özel sektör tarafından kullanılan dış borçlanmanın yatırımlarda etkin olarak kullanılamadığı belirtilebilir. Kısa dönem etkiler değerlendirildiğinde ise kamu dış borcunun ekonomik büyüme üzerindeki negatif etkisinin özel sektör dış borcunun yaklaşık iki katı olduğu tespit edilmiştir.

Tablo 9. BRICS-T Ülkeleri Kısa Dönem Tahmin Sonuçları

\begin{tabular}{lllllll}
\hline Bağımlı Değişken: EB & & & & & \\
\hline Bağımsız Değişken & Brezilya & Çin & Hindistan & Rusya & G. Afrika & Türkiye \\
\hline$\Delta$ TDB & $-8.310^{* * * *}$ & $-5.935^{* * *}$ & $-11.074^{* * * *}$ & $-10.567^{* * * *}$ & 0.786 & $-15.546^{* * *}$ \\
$\left(\varphi_{i}\right)$ & $-0.808^{* * *}$ & $-0.327^{* *}$ & $-1.126^{* * * *}$ & $-0.884^{* * * *}$ & $-0.682^{* * * *}$ & $-0.922^{* * * *}$ \\
$\Delta$ KDB & $-7.824^{* * *}$ & -2.899 & $-6.614^{* *}$ & $-11.383^{* * *}$ & -0.024 & $-18.514^{* * * *}$ \\
$\left(\varphi_{i}\right)$ & $-0.812^{* * *}$ & -0.099 & $-0.238^{* *}$ & $-0.933^{* * *}$ & $-0.661^{* * *}$ & $-0.893^{* * *}$ \\
$\Delta$ ÖDB & $-6.118^{* *}$ & -0.628 & -2.035 & $-3.233^{* * *}$ & 0.121 & $-11.326^{* * *}$ \\
$\left(\varphi_{i}\right)$ & $-0.715^{* * *}$ & -0.211 & $-0.835^{* * *}$ & $-0.784^{* * *}$ & $-0.558^{* * *}$ & $-0.784^{* * *}$ \\
\hline
\end{tabular}

Not: $\left(\varphi_{i}\right)$, hata düzeltme terimini; ${ }^{* * * * * *},{ }^{*}$ sirasiyla $\% 1, \% 5$ ve $\% 10$ anlamlllı düzeylerini göstermektedir.

Tablo 9, hata düzeltme katsayısına dayalı ülke bazında kısa dönem bulguları özetlemektedir. Toplam dış borç açısından, Brezilya, Çin, Hindistan, Rusya ve Türkiye için hata düzeltme katsayıları negatif ve anlamlıdır. Bu ülkelerde toplam dış borçlar kısa dönemde uzun döneme doğru dengeye geleceği ve kısa dönemde de toplam diş borçların etkili olduğu görülmektedir. Tüm ülkelerde beklenildiği gibi tüm katsayılar negatif yöndedir. En yüksek katsayının Türkiye'ye, en düşük katsayının ise Çin'e ait olduğu görülmektedir. Kamu dış borcunun ekonomik büyüme üzerindeki kısa dönemli etkilerine bakıldığında, Brezilya, Hindistan, Rusya ve Türkiye'nin hata düzeltme katsayılarının negatif ve anlamlı olduğu tespit edilmiştir. Kamu dış borcundaki \%1'lik bir artış kısa dönemde Türkiye için \%18, Rusya için \%11, Brezilya için $\% 7$, Hindistan için \%6 düzeyinde ekonomik büyümeyi azaltmaktadır. Özel sektör dış borcu için değerlendirildiğinde, Brezilya, Rusya ve Türkiye'de katsayılar kısa dönemde anlamlı ve negatif yöndedir. Brezilya için özel sektör dış borcu \%1'lik bir artış olduğunda ekonomik büyüme yaklaşık \%6 düzeyinde azalmaktadır. Aynı yöndeki negatif etki Rusya için \%3 ve Türkiye için \%11 düzeylerindedir. Kısa dönemli sonuçlar Çin ve Güney Afrika için anlamlı sonuçlar göstermemiştir. Bu ülkelerde kamu ve özel sektör dış borç türlerinin kısa dönemden ziyade uzun dönemde etkili oldukları belirtilebilir. Genel olarak değerlendirildiğinde tüm ülkeler için hem kısa dönem hem de uzun dönemde en yüksek negatif etkiye sahip olan dış borç türü kamu dış borcudur. Kamu dış borçlanmasının ekonomik büyüme üzerindeki kısa dönem negatif ve anlamlı etkisi sırasıyla Türkiye, Rusya, Brezilya ve Hindistan şeklinde büyükten küçüğe doğru ülkeler arasında sıralanmaktadır.

\section{DEĞERLENDIRME VE SONUÇ}

Ekonomi teorileri makul bir borç seviyesinin hem gelişmekte olan hem de gelişmiş ülkelerin ekonomik büyümelerini artırmalarına yardımcı olması gerektiğini öne sürmektedir. Dış borçlanma ile ilgili teorik yaklaşımlardan dışlama hipotezi, borç fazlası teorisi ve borç Laffer Eğrisi yaklaşımları yüksek borç seviyelerinin ekonomik büyümeyi olumsuz etkileyeceğini öne 
sürmektedir. Dış borçlanma ile elde edilen kaynakların verimli alanlarda kullanılması, dış kaynağın kullanıldığı alandan elde edilen gelirin en az borç servisini karşılayacak düzeyde olması, dış borçlanmanın uzun vadeli ve düşük maliyetli gerçekleştirilmesi ekonomik büyüme üzerindeki olumsuz etkilerini azaltacaktır. Dış borçların ekonomik etkileri, ülkelerin sağladığı dış borçlanma kaynaklarını kullanım tercihi, ülkelerin ekonomik koşulları ve dış borçlanma koşullarına (vade, maliyet vb.) göre farklılık gösterebilmektedir.

Bu çalışmada 1997-2019 yılları arasında Türkiye ve BRICS ülkelerinde dış borç bileşenlerinin ekonomik büyüme üzerindeki etkisi tahmin edilmiştir. Buradan hareketle diş borcun bileşenleri toplam dış borç, kamu dış borcu ve özel sektör dış borcu olarak belirlenmiştir. Panel ARDL analizinden elde edilen sonuçlara göre tüm ülkeler bazında toplam diş borç, kamu dış borcu ve özel sektör diş borcunun ekonomik büyüme üzerinde uzun dönemde negatif etki gösterdiği tespit edilmiştir. Bunun yanında hata düzeltme katsayısının negatif ve istatistiksel olarak anlamlı olması değişkenler arasındaki ilişkinin kısa dönemden uzun döneme doğru dengeye geleceğini göstermektedir. Uzun dönemde elde edilen katsayılara göre özel sektör dış borcu ekonomik büyüme üzerinde en fazla negatif etkide bulunan değişken olarak tespit edilmiştir. Uzun dönemde toplam dış borç, kamu dış borcu ve özel sektör dış borcunun GSYİH oranındaki $\% 1$ 'lik bir artış ekonomik büyüme oranı üzerinde sırasıyla \%1.73, \%1.19 ve \%2.24 oranında bir azalışa, kısa dönemde ise yine sırasıyla \%8.44, \%7.87 ve \%3.75 oranında bir azalışa neden olmaktadır. Katsayılara göre değerlendirildiğinde, dış borçlanmanın ekonomik büyüme üzerindeki negatif etkisi kısa dönemde uzun döneme göre daha büyüktür.

Ülke bazında elde edilen kısa dönemli sonuçlar ise Brezilya, Çin, Hindistan, Rusya ve Türkiye'de toplam dış borçların kısa dönemde ekonomik büyüme üzerinde negatif etkiye sahip olduğunu göstermektedir. Toplam dış borç tutarı ekonomik büyüme üzerinde kısa dönemde Brezilya'da yaklaşık \%8, Çin'de \%5, Hindistan'da \%11, Rusya'da \%10 ve Türkiye'de ise \%15 oranında negatif etkiye sahip olduğu belirlenmiştir. Kamu dış borcundaki \%1 birimlik artışın kısa dönemde Türkiye'de \%18, Rusya'da \%11, Brezilya'da \%7, Hindistan'da \%6 düzeyinde ekonomik büyümeyi azalttığı tespit edilmiştir. Brezilya için özel sektör dış borcu \%1 birim arttığında ekonomik büyüme yaklaşık \%6 düzeyinde azaldığı, aynı yöndeki kısa dönemli negatif etkinin Rusya için \%3, Türkiye için \%11 düzeylerinde olduğu tespit edilmiştir. Araştırma bulgularına göre üç temel sonuca ulaşılmıştır. Birinci sonuç, ilgili ülke ve dönem dikkate alındığında tüm diş borç bileşenlerinin ekonomik büyüme üzerinde olumsuz etkide bulunduğudur. İkinci sonuç, benzer negatif yönlü etkinin kısa dönemde uzun döneme göre daha etkili bulunduğunu göstermektedir. Son olarak ise dış borç bileşenleri arasında hem kısa dönem hem de uzun dönemde kamu dış borçlarının ekonomik büyüme üzerinde daha fazla olumsuz etkiye sahip olduğu belirlenmiştir. Bu sonuçlar, borçluluk düzeyi yüksek olan ülkelerin ekonomik büyüme olanaklarının kısıtlanacağını savunan "Borç Fazlası Hipotezi” ile uyumlu ve konuyla ilgili literatürdeki bazı araştırmaların sonuçlarıyla da benzerlik göstermektedir.

$\mathrm{Bu}$ çalışmanın bulguları, dış borcun daha yüksek yatırım getirisi sağlayacak sektörlere tahsis edilmesi gerekliliğini, projelerin önceliklerini dikkate alarak dış borçların verimli alanlarda kullanılmasını, gelişmekte olan ülkelerde yurt içi tasarrufların artırılmasını ve ekonominin dış borca bağımlılı̆̆ının azaltılarak borç fazlası sorunu ile karşılaşılmaması gerekliliğini ortaya koymaktadır. Borç yönetiminde etkili politika yapıcı ve uygulayıcılar, uzun vadeli ekonomik performansın sürdürülmesini sağlayacak ekonomik faaliyetlere yönelik diş borcun doğru şekilde kullanımını, dış borçlanmanın en önemli nedenlerinden olan bütçe açıkları ve cari açığı azaltacak politikalar ile dış borç ödeme göstergelerinde iyileşmenin sağlanması için ihracat 
gelirlerini artıracak politikaları önemsemelidirler. Ayrıca, kamu borç yöneticileri ve hükümetlerin ödünç alınan fonların verimli kullanımını sağlayacak bir izleme mekanizması oluşturmaları ve dış borç eşik seviyesinin kısa ve uzun vadede belirlenip ülke ekonomilerinde ortaya çıkaracağı ağır yükten kaçınmak için gerekli önlemleri almaları gereklidir.

\section{KAYNAKÇA}

ABDULLAHI, M.M., ABU BAKAR, N.A.B. ve HASSAN, S.B. (2016). "Debt Overhang versus Crowding Out Effects: Understanding the Impact of External Debts on Capital Formation in Theory", International Journal of Economics and Financial Issues, 6(1), 271-278.

ADEDOYIN, L.I., BABALOLA, M.B., OTEKUNRI, A.O. ve ADEOTI, J.O. (2016). "External Debt and Economic Growth: Evidence from Nigeria", Economica, 12(6), 179-194.

AĞIR, H. (2016). “Türkiye'de Dış Borçlanma ve Ekonomik Büyüme İlişkisinin Nedensellik Analizleri”, Sosyal Ekonomik Araştırmalar Dergisi, 16(32), 204-221.

AKÇAY, S. ve ÇELİK, N. (2020). "Dış Borçların Sürdürülebilirliği: ECOWAS Ülkeleri Örneği”, SiYYASAL: Journal of Political Sciences, 29(2), 207-230.

ALI, R. ve MUSTAFA, U. (2012). "External Debt Accumulation and Its Impact on Economic Growth in Pakistan", The Pakistan Development Review, 51(4), 79-95.

ANNING, L., OFORI, C.F. ve AFFUM, E.K. (2016). "The Impact of Government Debt on the Economic Growth of Ghana: A Time Series Analysis from 1990-2015”, International Journal of Innovation and Economic Development, 2, 31-39.

BAKAR, N.A. ve HASSAN, S. (2008). "Empirical Evaluation on External Debt of Malaysia”, International Business and Economics Research Journal, 7(2), 95-108.

BALKANLI, A.O. (2019). "External Debt and Growth Relationship in Turkey: An Econometric Analysis (1983-2017)", Journal of Strategic Research in Social Science, 5 (1), 29-46.

BAYIR, M. (2020). "Dış Borçlanmanın Ekonomik Büyüme Üzerindeki Etkisi”, Dicle Üniversitesi İ̈BF Dergisi, 10(20), 382-395.

BAYRAK, M. ve ESEN, Ö. (2012). "The Analysis of Turkey from the Viewpoint of the Foreign Debt Structure and the Impact of the Foreign Borrowing on Economic Growth", International Research Journal of Finance and Economics, 93, 24-43.

BENLİ, M. (2020). "External Debt Burden - Economic Growth Nexus in Turkey". Social Sciences Research Journal, 9 (1): 107-116.

BİÇER, B. (2020). "Diş Borç-Ekonomik Büyüme İlişkisi: 1970-2017 Dönemi Türkiye Örneği”, Osmaniye Korkut Ata Üniversitesi İktisadi ve İdari Bilimler Fakültesi Dergisi, 4(1), 23-45.

BİLGINOĞLU, M.A. ve AYSU, A. (2008). "D1ş Borçların Ekonomik Büyüme Üzerindeki Etkisi: Türkiye Örneği”, Erciyes Üniversitesi İktisadi ve İdari Bilimler Fakültesi Dergisi, 31, 1-23. 
CASARES, E.R. (2015). “A Relationship Between External Public Debt and Economic Growth”, Estudios Económicos, 30(2), 219-243.

CEBECİ MAZLUM, E. (2020). "Dış Borçlanma ve Ekonomik Büyüme Arasında Nedensellik İlişkisi: 1990-2016 Dönemi Latin Amerika Ülkeleri Örneği”, Ekonomi Bilimleri Dergisi, 12 (2), 145-162.

ÇİÇEK, H., GÖZEGİR, S. ve ÇEVİK, E. (2010). "Bir Maliye Politikası Aracı Olarak Borçlanma ve Ekonomik Büyüme İlişkisi: Türkiye Örneği (1990-2009)”, Cumhuriyet Üniversitesi İktisadi ve İdari Bilimler Dergisi, 11 (1), 141-156.

ÇÖĞÜRCÜ, İ. ve ÇOBAN, O. (2011). “Dış Borç Ekonomik Büyüme İlişkisi: Türkiye Örneği (1980-2009)", Karamanoğlu Mehmetbey Üniversitesi Sosyal ve Ekonomik Araştırmalar Dergisi, 2, 133-149.

DAO, H.T.T. ve OANH, D.H. (2017). "External Debt and Economic Growth in Vietnam: A Nonlinear Relationship", China-USA Business Review, 16(1), 1-13.

DAUD, S.N.M. (2020). "External Debt, Institutional Quality and Economic Growth”, Bulletin of Monetary Economics and Banking, 23(2), 221-238.

DEY, S.R. ve TAREQUE, M. (2020). "External Debt and Growth: Role of Stable Macroeconomic Policies", Journal of Economics, Finance and Administrative Science, 25(50), 185-204.

DOĞAN, I. ve BİLGİLI, F. (2014). "The Non-linear Impact of High and Growing Government External Debt on Economic Growth: A Markov Regime-switching Approach", Economic Modelling, 39, 213-220.

DORUK, Ö.T. (2018). “Diş Borçlar ve Ekonomik Büyüme: Türkiye Ekonomisinde 1970-2014 Dönemi İçin Ampirik Bir İnceleme”, Maliye Dergisi. 175, 96-114.

EHIKIOYA, B.I., OMANKHANLEN, A.E., OSUMA, G.O. ve INUA, O.I. (2020). "Dynamic Relations Between Public External Debt and Economic Growth in African Countries: A Curse or Blessing?", Journal of Open Innovation: Technology, Market, and Complexity, 6(3), 88: https://doi.org/10.3390/joitmc6030088.

ELA, M. ve PATA, U.K. (2020). "Türkiye İçin Dış Borcun Dışlama ve Borç Fazlası Hipotezlerinin Ampirik Analizi”, Akademik İncelemeler Dergisi, 15(1), 29-56.

ELBADAWI, I.A., NDULU, B.J. ve NDUNG'U, N. (1997). Debt Overhang and Economic Growth in Sub-Saharan Africa, IQBAL, Z. Ve KANBUR, R. (Editör), External Finance For Low-Income Countries içinde (s. 49-76), IMF Publishing, USA, https://www.elibrary.imf.org/doc/IMF071/02271-9781451957198/02271-

9781451957198/Other_formats/Source_PDF/02271-9781455286010.pdf. Erişim: 12.01.2021.

ERKAN, Ç., TUTAR, E., TUTAR, F. ve EREN, M.V. (2012). “Türkiye'nin Dış Borçlarının Analizi”, International Conference On Eurasian Economies 2012, http://www.eecon.info/papers/483.pdf. Erişim: 12.02.2021.

FELIX F.N. (2020). "Is External Debt Hampering Growth in the ECOWAS Region?", International Journal of Economics and Finance, 12(4), 54-66. 
GANIEV, J., BAIGONUSHOVA, D., MADMAROV, N. ve ABDIEVA, R. (2020). "External Debt and Economic Growth in Transition Countries: Case of Kyrgyzstan", MANAS Sosyal Araştırmalar Dergisi, 9(1), 60-75.

GÜL, E., KAMACI, A. ve KONYA, S. (2012). "D1ş Borcun Büyüme Üzerine Etkileri: Orta Asya Cumhuriyetleri ve Türkiye Örneği”, International Conference on Eurasian Economies 2012, https://www.avekon.org/papers/469.pdf. Erişim: 09.01.2021.

GÜRDAL, T. ve YAVUZ, H. (2015). “Türkiye'de Dış Borçlanma-Ekonomik Büyüme İlişkisi: 1990-2013 Dönemi”, Maliye Dergisi, 168, 154-169.

HOTUNLUOĞLU, H. ve YAVUZER, M.T. (2020). "Diş Borç ve Ekonomik Büyüme Arasındaki İlişki: Türkiye (2000:Q1-2019:Q3)", İnsan ve Toplum Bilimleri Araştırmaları Dergisi , 9(5), 3930-3950.

HUSAIN, A.M. (1997). "Domestic Taxes and the External Debt Laffer Curve", Economica, 64(255), 519-525. https://www.jstor.org/stable/pdf/2554841.pdf. Erişim: 12.01.2021.

HUSSAIN, M.E., HAQUE, M. ve IGWIKE, R.S. (2015). "Relationship between Economic Growth and Debt: An Empirical Analysis for Sub-Saharan Africa", Journal of Economics and Political Economy, 2(2), 262-275.

IMF (2003). External Debt Statistics Guide for Compilers and Users. International Monetary Fund, Washington D.C., https://www.imf.org/external/pubs/ft/eds/eng/guide/file1.pdf. Erişim: 02.01.2021.

JILENGA, M.T., XU, H. ve GONDJE-DACKA, I.-M. (2016). “The Impact of External Debt and Foreign Direct Investment on Economic Growth: Empirical Evidence from Tanzania”, International Journal of Financial Research, 7(2), 154-162.

KARAGÖL, E. (2002). "The Causality Analysis of External Debt Service and GNP: The Case of Turkey" Central Bank Review 2 (1), 39-64. https://www.tcmb.gov.tr/wps/wcm/connect/EN/TCMB+EN/Main+Menu/Publications/ Central+Bank+Review/2002/Volume+2-1/. Erişim: 06.01.2021.

KARAGÖL, E. (2004). “A Critical Review of External Debt and Economic Growth Relationship: A Lesson For Indebtedness Countries”, Ege Akademik Bakış Dergisi, 4(1), 69-78.

KAZAKOVA, S. ve INABA, K. (2018). "Debt Sustainability in the Developing Countries: Case Study of the Kyrgyz Republic", The Ritsumeikan Economic Review, 67(4), 438453.

KHAN, R.E.A. ve GILL, A.R. (2009). "Crowding Out Effect of Public Borrowing: A Case of Pakistan”, MPRA Paper No. 16292, https://mpra.ub.unimuenchen.de/16292/3/MPRA_paper_16292.pdf. Erişim: 03.01.2021.

KHARUSI, S.A. ve ADA, M.S. (2018). "External Debt and Economic Growth: The Case of Emerging Economy", Journal of Economic Integration, 33(1), 1141-1157.

KRUGMAN, P. (1988). "Financing vs. Forgiving a Debt Overhang”, Journal of Development Economics, 29(3), 253-268. https://doi.org/10.1016/0304-3878(88)90044-2. 
KUTLU, S. ve YURTTAGÜLER, İ.M. (2016). “Türkiye'de Dış Borç ve Ekonomik Büyüme İlişkisi: 1998-2014 Dönemi İçin Bir Nedensellik Analizi”, Marmara Üniversitesi İktisadi ve İdari Bilimler Dergisi, 38(1), 229-248.

LIN, S. ve SOSIN, K. (2001). "Foreign Debt and Economic Growth”, Economics of Transition, 9(3), 635-655.

MYERS, S.C. (1977). "Determinants of Corporate Borrowing", Journal of Financial Economics, 5(2), 147-175. https://doi.org/10.1016/0304-405X(77)90015-0.

N'ZUE, F.F. (2020). "Is External Debt Hampering Growth in the ECOWAS Region?", International Journal of Economics and Finance, 12(4), 54-66.

NATH, S. (2020). "An Analysis of the Relationship among Economic Growth, External Debt and Exports in India (1970-2018)", Economy, 7(1), 59-68.

NDORICIMPA, A. (2017), "Threshold Effects of Debt on Economic Growth in Africa", African Development Review, 29(3), 471-484.

NDORICIMPA, A. (2020). "Threshold Effects of Public Debt on Economic Growth in Africa: A New Evidence”, Journal of Economics and Development, 22(2), 187-207.

NOUNAMO, H.Y.N., RACHDI, H. ve GUESMI, K. (2020). "External Debt and Economic Growth in CFA Countries: Political Institutions Matter?", International Journal of Current Science Research and Review, 3(3), 14-28.

OHIOMU, S. (2020). "External Debt and Economic Growth Nexus: Empirical Evidence From Nigeria", The American Economist, 65(2), 330-343.

OLUSEYI, A.S. (2013). "The Upshot of External Debt on Economic Growth in West African Countries: A Panel Data Approach”, MPRA Paper No. 52555, https://mpra.ub.unimuenchen.de/52555/. Erişim: 07.01.2021.

OMODERO, C.O. ve ALPHEAUS, O.E. (2019). "The Effect of Foreign Debt on the Economic Growth of Nigeria", Management Dynamics in the Knowledge Economy, 7(3), 291306.

ÖZEL, H.A. (2015). “Analysis of Foreign Debt and Economic Growth in Turkey by Using Core Regression", Eurasian Econometricsi Statistics\&Emprical Economics Journal, $1,18-31$.

ÖZTÜRK, S., ÇINAR, U. ve EMEK, M.L. (2019). "Kamu Dış Borçlanması ve Ekonomik Büyüme İlişkisi: Türkiye Üzerine Ampirik Bir Uygulama (1970-2016)”, ISPEC International Journal of Social Sciences \& Humanities, 3(1), 17-33.

PATA, U.K. ve ELA, M. (2020). Türkiye'de Borç Laffer Eğrisi Teori ve Uygulama. Gazi Kitabevi, Ankara.

PATTILLO, C., POIRSON, H. ve RICCI, L. (2004). "What are The Channels Through Which External Debt Affects Growth?”, IMF Working Paper 04/15, Washington, DC., https://www.elibrary.imf.org/doc/IMF001/...../Source_PDF/07873-

9781451891287.pdf. Erişim: 26.12.2020. 
PATTILlO, C., POIRSON, H. ve RICCI, L.A. (2011). “External Debt and Growth”, Review of Economics and Institutions, 2(3), 1-30, http://www.rei.unipg.it/rei/article/view/45. Erişim: 16.01.2021.

PESARAN, M.H. (2007). “A Simple Panel Unit Root Test in the Presence of Cross-Section Dependence", Journal of Applied Econometrics, 2(2), 265-312.

PRESBITERO, A.F. (2006). “The Debt-Growth Nexus: A Dynamic Panel Data Estimation”, Rivista Italiana Degli Economisti, 11(3), 417-462.

SACHS, J. (1989). “The Debt Overhang of The Developing Countries”. G.A. Calvo vd. (ed.), Debt, Stabilization and Development (80-102). Basil Blackwell, Oxford.

SHABBIR, S. (2013). "Does External Debt Affect Economic Growth: Evidence from Developing Countries", SBP Working Paper Series No: 63: 1-20, https://www.sbp.org.pk/repec/sbp/wpaper/wp63.pdf. Erişim: 10.01.2021.

SHKOLNYK, I. ve KOILO, V. (2018). "The Relationship Between External Debt and Economic Growth: Empirical Evidence from Ukraine and Other Emerging Economies", Investment Management and Financial Innovations, 15(1), 387-400.

SICHULA, M. (2012). "Debt Overhang and Economic Growth in HIPC Countries: The Case of Southern African Development Community (SADC)", International Journal of Economics and Finance, 4(10), 82-92. http://dx.doi.org/10.5539/ijef.v4n10p82.

SILVA, J. (2020). "Impact of Public and Private Sector External Debt on Economic Growth: The Case of Portugal", Eurasian Economic Review, 10, 607-634. https://doi.org/10.1007/s40822-020-00153-2.

TOKTAŞ, Y., ALTINER, A. ve BOZKURT, E. (2019). “The Relationship Between Turkey’s Foreign Debt and Economic Growth: An Asymmetric Causality Analysis", Applied Economics, 51(26), 2807-2817.

TUFFOUR, J.K. (2012a). "External Debt Threshold and Economic Growth Loss in Ghana", Humberside Journal of Social Sciences, 1(1), 66-75.

TUFFOUR, J.K. (2012b). “An Analysis of The Effect of External Debt on Crowding-Out of Private Investment in Ghana", Journal of Business Research, 6(1\&2), 73-83.

UYSAL, D., ÖZER, H. ve MUCUK, M. (2009). "Dış Borçlanma ve Ekonomik Büyüme İlişkisi: Türkiye Örneği (1965-2007)”, Atatürk Üniversitesi İktisadi ve İdari Bilimler Dergisi 23 (4), 161-178.

UZUN, A., KARAKÖY, Ç., KABADAYI, B. Ve EMSEN, O.S. (2012). "The Impacts of External Debt on Economic Growth in Transition Economies", Chinese Business Review, 11(5), 491-499.

WESTERLUND, J. (2008). "Panel Cointegration Tests of The Fisher Effect", Journal of Applied Econometrics, 23(2), 193-223.

WORLD BANK (2020). International Debt Statistics 2021. https://openknowledge.worldbank.org/handle/10986/34588. Erişim: 09.01.2021. 
YARAŞIR TÜLÜMCE, S. ve YAVUZ, E. (2017). "Türkiye'de Borçlanma ve Ekonomik Büyüme Arasındaki İlişki”, Uluslararası Yönetim İktisat ve İşletme Dergisi, 13(13), ICMEB17 Özel Sayıs1, 1034-1048.

YILDIZ, F. (2019). “Türkiye Ekonomisinde Dış Borç, Ekonomik Büyüme ve Cari İşlemler Dengesi İlişkisinin Analizi”, Manas Sosyal Araştırmalar Dergisi, 8(4) , 3416-3438.

ZHANG, B., DAWOOD, M. ve AL-ASFOUR, A. (2020). "External Debt and Economic Growth: A Dynamic Panel Study of Granger Causality in Developing Countries", Journal of Asian Finance, Economics and Business, 7(11), 607-617. 